\title{
A new species of Anobothrus (Polychaeta, Ampharetidae) from the Weddell Sea (Antarctica), with notes on habitat characteristics and an updated key to the genus
}

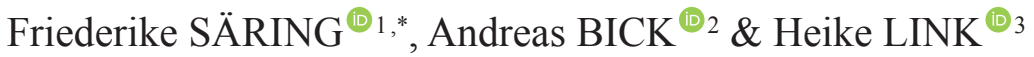 \\ ${ }^{1,3}$ University of Rostock, Interdisciplinary Faculty, Department Maritime Systems, \\ Albert-Einstein-Str. 21, D-18059 Rostock, Germany. \\ ${ }^{1,3}$ University of Rostock, Institute of Biology, Marine Biology, Albert-Einstein-Str. 3, \\ D-18059 Rostock, Germany. \\ ${ }^{2}$ University of Rostock, Institute of Biology, General and Systematic Zoology, Universitätsplatz 2, \\ D-18055 Rostock, Germany. \\ *Corresponding author: friederike.saering@uni-rostock.de \\ 2Email: bick-andreas@t-online.de \\ 32Email: heike.link@uni-rostock.de \\ ${ }^{1}$ urn:Isid:zoobank.org:author:1C21E24A-79A8-4D67-B9BA-4C9F534E073F \\ ${ }^{2}$ urn:1sid:zoobank.org:author:3E678C85-D5E8-4A43-897D-A08E4D593602 \\ ${ }^{3}$ urn:lsid:zoobank.org:author:0D77C070-3BC1-406F-970F-59FF26386938
}

\begin{abstract}
Benthic samples were collected during two expeditions near the Antarctic Peninsula and in the South-Eastern Weddell Sea. During these studies, a new species of Ampharetidae Malmgren, 1867, Anobothrus konstantini Säring \& Bick sp. nov., was found. Here we present a detailed description of this species. We used the traditional light microscope and scanning electron microscope (SEM) to identify and describe the diagnostic characters: a circular glandular band on segment 6; an elongate ridge between the notopodia on segment 12 and modified notochaetae on this segment; 16 thoracic, two intermediate and ten abdominal segments. For the first time, micro-computed tomography (microCT) was used for a species description of Anobothrus. Micro-CT provided information on the shape of the prostomium (Ampharete-type) and the arrangement of branchiae (four pairs in two rows, without a gap). In addition, we provide quantitative information on the environmental niche based on sediment parameters (chlorophyll $a$ content, organic matter content, chloroplast equivalent, grain size) for the new Anobothrus species, relevant for, e.g., species distribution modelling. Finally, an identification key for all Anobothrus species is provided.
\end{abstract}

Keywords. Anobothrus konstantini Säring \& Bick sp. nov., Antarctic Peninsula, ecology, Filchner Trough, micro-CT analysis, SEM.

Säring F., Bick A. \& Link H. 2022. A new species of Anobothrus (Polychaeta, Ampharetidae) from the Weddell Sea (Antarctica), with notes on habitat characteristics and an updated key to the genus. European Journal of Taxonomy 789: 130-152. https://doi.org/10.5852/ejt.2022.789.1637 


\section{Introduction}

Polychaetes are one of the most speciose and dominant macrofaunal group of the Southern Ocean benthos (Clarke \& Johnston 2003), and they are distributed in all substrates ranging from intertidal to abyssal depths (Schüller \& Ebbe 2014). Despite comprehensive recent efforts, many species remain unknown. Many of the most abundant species in the Southern Ocean region belong to the hemi-sessile and tube-dwelling Ampharetidae (Schüller \& Ebbe 2007, 2014). This family is one of the most abundant and species-rich among polychaetes, including so far more than 300 described species worldwide (Jirkov 2011; Bonifácio et al. 2015; Alalykina \& Polyakova 2020; World Register of Marine Species, http://www.marinespecies.org). The taxonomy of Ampharetidae is complex and poorly resolved, with insufficient diagnoses. Major difficulties and confusion refer to different terminology and counting of segments and chaetigers following the prostomium. A conflict concerns the chaetae (paleae) of segment 2, which are excluded in the counts of chaetigers by some authors but included by others (Reuscher et al. 2009). The mode of counting needs to be defined to avoid uncertainties of the different counting expressions and misinterpretations. The terminology used in this work for counting segments, chaetigers, and uncinigers is shown schematically for a specimen of Anobothrus (Fig. 1).

Within the Ampharetidae Malmgren, 1867, Anobothrus Levinsen, 1884 is one of the most species-rich and diverse genera (Schüller \& Jirkov 2013; Bonifácio et al. 2015). Anobothrus is characterized by modifications of the fourth-, fifth- or sixth-to-last thoracic unciniger with dorsally elevated notopodia and/or modified notochaetae and/or a transverse dorsal ridge between the elevated notopodia. In this genus, 22 species are currently considered valid, three of them having been described recently (Alalykina \& Polyakova 2020). Species of the genus Anobothrus show a worldwide distribution (Alalykina \& Polyakova 2020: table 3). Fourteen Anobothrus species have been described from the Pacific (Malmgren 1866; Hartmann-Schröder 1965; Fauchald 1972; Hilbig et al. 2000; Jirkov 2009; Reuscher et al. 2009; Imajima et al. 2013; Alalykina \& Polyakova 2020), while only 5 species are reported from polar latitudes: A. laubieri (Desbruyères, 1979) from the Arctic Ocean and A. antarctica Monro, 1939, A. paleaodiscus Schüller \& Jirkov, 2013, A. pseudoampharete Schüller, 2008 and A. wilhelmi Schüller \& Jirkov, 2013 from the Southern Ocean.

Non-biological (seasonality of sea-ice extent, low bottom temperatures, currents, wind) and biological (seasonal primary production and nutrient pulses) parameters typical for polar systems shape the complexity of the benthic ecosystem in the Southern Ocean (Gutt et al. 2018). This study presents a

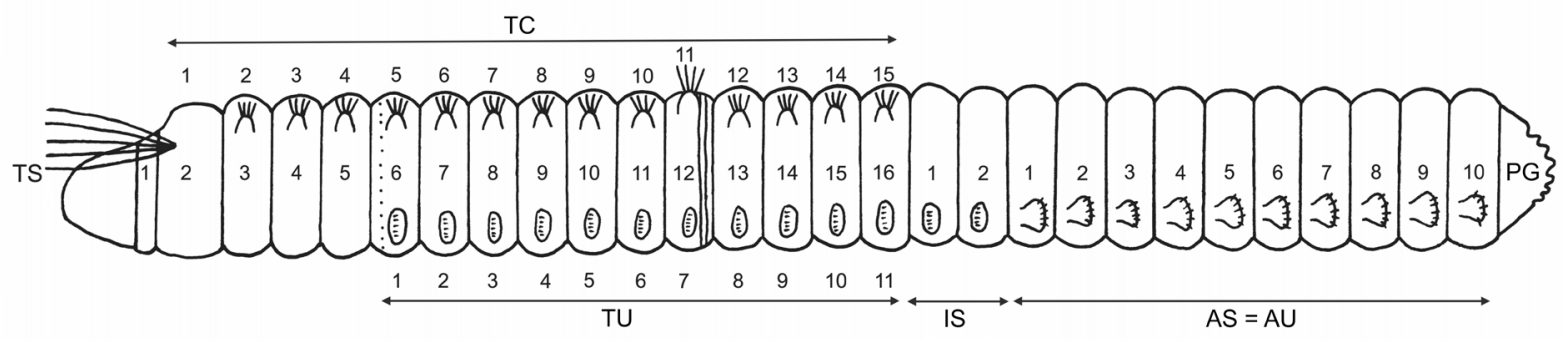

Fig. 1. Schematic lateral view of Anobothrus konstantini Säring \& Bick sp. nov. Abbreviations: see Material and methods. Vertical dotted line in TS6 represents circular glandular band. Vertical lines in TS12 represent elongated ridge between notopodia. 
detailed description of the abiotic parameters encountered at sites sampled for polychaetes to characterize the ecological niche, which builds a baseline for potential habitat modelling (Jansen et al. 2018) and species distribution modelling (Meißner et al. 2014) for the new species of Anobothrus.

The aim of this paper is to describe a new species of Anobothrus discovered during ecological studies in the Antarctic Peninsula area and in the Weddell Sea (Säring et al. submitted) including a revised key for all species of Anobothrus described worldwide. We show how the micro-CT method can help to describe diagnostic features that are otherwise difficult to recognize in poorly preserved individuals. We finally present the key environmental factors that characterize the habitat of this species.

\section{Material \& Methods}

\section{Study area and sample collection}

Twelve specimens of Anobothrus were collected from 8 of 16 sampled stations during two expeditions with the RV Polarstern. The tip of the Antarctic Peninsula (Drake Passage, Bransfield Strait, NorthWestern Weddell Sea) was explored during expedition PS 81 (22 Jan.-18 Mar. 2013, Gutt et al. 2013), while the Filchner Trough area in the South-Eastern Weddell Sea was investigated during PS 96 (6 Dec. 2015-14 Feb. 2016, Schröder et al. 2016) (Table 1, Fig. 2; Säring et al. submitted). Water depth at the sampled stations ranged from 355 to $755 \mathrm{~m}$.

Samples were collected with a MUC10 equipped with eight plexiglass core liners (inner diameter $94 \mathrm{~mm}$, surface area $69.4 \mathrm{~cm}^{2}$; Säring et al. submitted). For macrofaunal samples, sediments were sieved over a $500-\mu \mathrm{m}$ mesh and fixed in a $4 \%$ formaldehyde-seawater solution (borax-buffered). More details on sediment core handling can be found in Säring et al. (submitted). For the comparison of spatial distribution, we calculated the total number of individuals per identified taxon per $\mathrm{m}^{2}$ from the top until the bottom of the core.

For later morphological analyses, faunal samples were preserved in $70 \%$ ethanol. Environmental data from sediments $(\mathrm{TOC}=$ total organic carbon; $\mathrm{Chl} a=$ chlorophyll $a$ content; $\mathrm{CPE}=$ chloroplastic equivalent, grain size) were obtained from additional samples up to $5 \mathrm{~cm}$ depth within the same or additional MUC cores and have been published elsewhere (Veit-Köhler et al. 2018; Säring et al. 2021a, b; Vanreusel et al. 2021 a, b). Here, we used the sediment layer 0-1 cm for the comparison of the environmental parameters associated with the new species. Data for salinity and temperature of bottom water were obtained from data collected by the CTD at the same stations (Schröder et al. 2013, 2016). Among the different regions, salinity varied from $34.45 \mathrm{psu}$ in the North-Western Weddell Sea (station PS81-162-2) to 34.67 psu in the North Filchner Trough region (station PS96-017-3). The bottom temperature ranged from the lowest, $-1.9^{\circ} \mathrm{C}$, in the North-Western and South-Eastern Weddell Seas to $0.7^{\circ} \mathrm{C}$ in the Drake Passage.

\section{Morphology}

Specimens were examined using an Olympus SZH10 stereo microscope and an Olympus BH2 light microscope. Photographs were taken with an Olympus SZX10 stereo microscope, an Olympus BX51 microscope and an Olympus UC30 camera. Specimens were stained with methyl blue and ShirlastainA to visualize specific body regions and structures. The staining fades completely when the specimens are returned to ethanol. Three specimens were transferred through a graded ethanol series in acetone and critical point dried with a Leica EM CPD300. Two of them were attached to a stub and covered with gold palladium and used for scanning electron microscopy (SEM). Scanning electron microscopy was carried out using a Zeiss DSM 960A microscope. The anterior end of the third specimen was used for the analysis with the micro-CT machine (Xradia 410 Versa, X-ray Microscope). The newly collected 
SÄRING F. et al., New species of Anobothrus (Ampharetidae, Polychaeta)

Table 1. Station list and sampling during RV Polarstern expeditions PS 81 (22 Jan.-18 Mar. 2013) around the Antarctic Peninsula (Drake Passage, Bransfield Strait, North-Western Weddell Sea) and PS 96 (6 Dec. 2015-4 Feb. 2016) to the South-Eastern Weddell Sea (South-Filchner Trough, NorthFilchner Trough) with the abundance of Anobothrus konstantini Säring \& Bick sp. nov. (No. of ind.) for each station. Sediment samples for environmental characterization were collected with the multicorer at the same stations (Säring et al. 2021a; Vanreusel et al. 2021a). Mean and standard deviation of environmental parameters are given for each station. Sediment parameters: $\mathrm{Chl} a=$ content of chlorophyll $a ; \mathrm{CPE}=$ sum of chlorophyll $a$ and phaeopigments; TOC $\%=$ total organic carbon; Silt $\&$ Clay $\%=$ grain size fraction $<63 \mu \mathrm{m}$; Sand $\%=$ grain size fraction $>63$ and $<500 \mu \mathrm{m}$; Coarse Sand $\%=$ grain size fraction $>500 \mu \mathrm{m}$.

\begin{tabular}{|c|c|c|c|c|c|c|c|c|c|c|c|}
\hline Region & Station no. & Date & $\begin{array}{c}\text { Latitude } \\
\text { Longitude }\end{array}$ & $\begin{array}{c}\text { No. } \\
\text { of } \\
\text { ind. }\end{array}$ & $\begin{array}{c}\text { Depth } \\
{[\mathrm{m}]}\end{array}$ & $\begin{array}{c}\mathrm{Chl} a \\
{\left[\mu \mathrm{g} \mathrm{g^{-1 } ]}\right.}\end{array}$ & $\begin{array}{c}\mathrm{CPE} \\
{\left[\mu \mathrm{g} \mathrm{g}^{-1}\right]}\end{array}$ & ТОС\% & $\begin{array}{l}\text { Silt \& } \\
\text { Clay\% }\end{array}$ & Sand\% & $\begin{array}{l}\text { Coarse } \\
\text { Sand \% }\end{array}$ \\
\hline \multirow{2}{*}{ 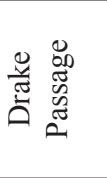 } & $\mathrm{P}$ & $\begin{array}{l}7 \text { Mar. } \\
2013\end{array}$ & $\begin{array}{l}62^{\circ} 16.35^{\prime} \mathrm{S} \\
61^{\circ} 10.23^{\prime} \mathrm{W}\end{array}$ & 1 & 355 & $\begin{array}{c}0.17 \\
\pm 0.15\end{array}$ & $\begin{array}{l}2.08 \\
\pm 1.3\end{array}$ & $\begin{array}{c}0.6 \\
\pm 0.0\end{array}$ & $\begin{array}{l}90.3 \\
\pm 0.4\end{array}$ & $\begin{array}{c}9.2 \\
\pm 0.4\end{array}$ & $\begin{array}{c}0.4 \\
\pm 0.1\end{array}$ \\
\hline & PS81-241 & $\begin{array}{l}9 \text { Mar. } \\
2013\end{array}$ & $\begin{array}{c}62^{\circ} 6.60^{\prime} \mathrm{S} \\
60^{\circ} 36.50^{\prime} \mathrm{W}\end{array}$ & 1 & 403 & $\begin{array}{c}0.16 \\
\pm 0.06\end{array}$ & $\begin{array}{l}0.28 \\
\pm 0.1\end{array}$ & $\begin{array}{c}0.8 \\
\pm 0.0\end{array}$ & $\begin{array}{l}89.0 \\
\pm 3.5\end{array}$ & $\begin{array}{c}7.0 \\
\pm 1.3\end{array}$ & $\begin{array}{c}4.0 \\
\pm 4.9\end{array}$ \\
\hline \multirow{5}{*}{  } & $\mathrm{P}$ & $\begin{array}{c}27 \text { Jan. } \\
2013\end{array}$ & $\begin{array}{c}62^{\circ} 26.93^{\prime} \mathrm{S} \\
56^{\circ} 17.05^{\prime} \mathrm{W}\end{array}$ & 0 & 425 & $\begin{array}{c}0.48 \\
\pm 0.00 \\
\end{array}$ & $\begin{array}{r}1.74 \\
\pm 0.2 \\
\end{array}$ & $\begin{array}{c}0.7 \\
\pm 0.0\end{array}$ & $\begin{array}{c}57.8 \\
\pm 10.0 \\
\end{array}$ & $\begin{array}{r}31.2 \\
\pm 2.1 \\
\end{array}$ & $\begin{array}{r}11.0 \\
\pm 7.9 \\
\end{array}$ \\
\hline & PS81-202 & $\begin{array}{c}27 \text { Feb. } \\
2013\end{array}$ & $\begin{array}{l}62^{\circ} 56.00^{\prime} \mathrm{S} \\
58^{\circ} 0.55^{\prime} \mathrm{W}\end{array}$ & 0 & 757 & $\begin{array}{c}0.92 \\
\pm 0.00 \\
\end{array}$ & $\begin{array}{r}5.33 \\
\pm 1.7 \\
\end{array}$ & $\begin{array}{c}1.1 \\
\pm 0.0 \\
\end{array}$ & $\begin{array}{r}85.7 \\
\pm 0.3 \\
\end{array}$ & $\begin{array}{r}14.0 \\
\pm 0.5 \\
\end{array}$ & $\begin{array}{c}0.2 \\
\pm 0.3 \\
\end{array}$ \\
\hline & PS81-217 & $\begin{array}{c}2 \text { Mar. } \\
2013\end{array}$ & $\begin{array}{c}62^{\circ} 53.25^{\prime} \mathrm{S} \\
58^{\circ} 14.13^{\prime} \mathrm{W}\end{array}$ & 2 & 532 & $\begin{array}{c}0.31 \\
\pm 0.13 \\
\end{array}$ & $\begin{array}{r}1.42 \\
\pm 1.1 \\
\end{array}$ & $\begin{array}{c}0.4 \\
\pm 0.0\end{array}$ & $\begin{array}{l}38.2 \\
\pm 3.3 \\
\end{array}$ & $\begin{array}{l}43.1 \\
\pm 0.8 \\
\end{array}$ & $\begin{array}{r}18.7 \\
\pm 2.5 \\
\end{array}$ \\
\hline & PS8 & $\begin{array}{l}2 \text { Mar. } \\
2013\end{array}$ & $\begin{array}{c}62^{\circ} 56.94^{\prime} \mathrm{S} \\
58^{\circ} 25.73^{\prime} \mathrm{W}\end{array}$ & 0 & 688 & $\begin{array}{c}0.74 \\
\pm 0.00\end{array}$ & $\begin{array}{l}2.63 \\
\pm 2.0\end{array}$ & $\begin{array}{c}1.1 \\
\pm 0.0\end{array}$ & $\begin{array}{l}79.6 \\
\pm 4.3\end{array}$ & $\begin{array}{r}18.1 \\
\pm 2.3\end{array}$ & $\begin{array}{c}2.3 \\
\pm 2.1\end{array}$ \\
\hline & PS81-225 & $\begin{array}{l}4 \text { Mar. } \\
2013\end{array}$ & $\begin{array}{c}62^{\circ} 56.08^{\prime} \mathrm{S} \\
58^{\circ} 40.76^{\prime} \mathrm{W}\end{array}$ & 1 & 543 & $\begin{array}{c}0.13 \\
\pm 0.11 \\
\end{array}$ & $\begin{array}{l}0.90 \\
\pm 0.9\end{array}$ & $\begin{array}{c}0.7 \\
\pm 0.0 \\
\end{array}$ & $\begin{array}{r}68.2 \\
\pm 3.0 \\
\end{array}$ & $\begin{array}{r}24.0 \\
\pm 0.7 \\
\end{array}$ & $\begin{array}{c}7.8 \\
\pm 2.3 \\
\end{array}$ \\
\hline \multirow{3}{*}{  } & PS81-120 & $\begin{array}{l}28 \text { Jan. } \\
2013\end{array}$ & $\begin{array}{c}63^{\circ} 4.78^{\prime} \mathrm{S} \\
54^{\circ} 31.45^{\prime} \mathrm{W}\end{array}$ & 0 & 494 & $\begin{array}{c}9.31 \\
\pm 0.00\end{array}$ & $\begin{array}{l}18.27 \\
\pm 11.3\end{array}$ & $\begin{array}{c}1.1 \\
\pm 0.0\end{array}$ & $\begin{array}{r}84.0 \\
\pm 3.1\end{array}$ & $\begin{array}{r}15.8 \\
\pm 3.1\end{array}$ & $\begin{array}{c}0.3 \\
\pm 0.4\end{array}$ \\
\hline & PS81-162 & $\begin{array}{l}10 \text { Feb. } \\
2013\end{array}$ & $\begin{array}{c}64^{\circ} 0.11^{\prime} \mathrm{S} \\
56^{\circ} 44.43^{\prime} \mathrm{W}\end{array}$ & 0 & 223 & $\begin{array}{c}5.85 \\
\pm 0.00\end{array}$ & $\begin{array}{l}8.58 \\
\pm 2.8\end{array}$ & $\begin{array}{c}2.4 \\
\pm 0.0\end{array}$ & $\begin{array}{l}57.4 \\
\pm 1.3\end{array}$ & $\begin{array}{l}42.6 \\
\pm 1.3\end{array}$ & $\begin{array}{c}0.0 \\
\pm 0.0\end{array}$ \\
\hline & PS81 & $\begin{array}{l}11 \mathrm{Feb} . \\
2013\end{array}$ & $\begin{array}{c}63^{\circ} 50.97^{\prime} \mathrm{S} \\
56^{\circ} 25.24^{\prime} \mathrm{W}\end{array}$ & 0 & 517 & $\begin{array}{l}25.20 \\
\pm 0.00\end{array}$ & $\begin{array}{l}38.12 \\
\pm 4.2\end{array}$ & $\begin{array}{c}1.6 \\
\pm 0.0\end{array}$ & $\begin{array}{l}91.9 \\
\pm 0.5\end{array}$ & $\begin{array}{c}8.1 \\
\pm 0.5\end{array}$ & $\begin{array}{c}0.0 \\
\pm 0.0\end{array}$ \\
\hline \multirow{3}{*}{ 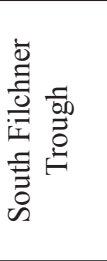 } & PS96-037 & $\begin{array}{c}16 \text { Jan. } \\
2016\end{array}$ & $\begin{array}{c}75^{\circ} 43.30^{\prime} \mathrm{S} \\
42^{\circ} 27.71^{\prime} \mathrm{W}\end{array}$ & 0 & 391 & $\begin{array}{c}0.33 \\
\pm 0.11 \\
\end{array}$ & $\begin{array}{l}4.41 \\
\pm 0.8 \\
\end{array}$ & $\begin{array}{c}0.4 \\
\pm 0.0 \\
\end{array}$ & $\begin{array}{l}77.7 \\
\pm 4.3 \\
\end{array}$ & $\begin{array}{l}20.1 \\
\pm 1.6 \\
\end{array}$ & $\begin{array}{c}2.2 \\
\pm 0.8 \\
\end{array}$ \\
\hline & PS96-061 & $\begin{array}{c}21 \text { Jan. } \\
2016\end{array}$ & $\begin{array}{l}76^{\circ} 05.93^{\prime} \mathrm{S} \\
30^{\circ} 18.23^{\prime} \mathrm{W}\end{array}$ & 1 & 468 & $\begin{array}{c}0.13 \\
\pm 0.03\end{array}$ & $\begin{array}{r}1.49 \\
\pm 0.1\end{array}$ & $\begin{array}{c}0.5 \\
\pm 0.1\end{array}$ & $\begin{array}{l}90.9 \\
\pm 2.1\end{array}$ & $\begin{array}{c}9.1 \\
\pm 2.1\end{array}$ & $\begin{array}{c}0.0 \\
\pm 0.0\end{array}$ \\
\hline & PS96-072 & $\begin{array}{c}24 \text { Jan. } \\
2016\end{array}$ & $\begin{array}{c}75^{\circ} 51.37^{\prime} \mathrm{S} \\
32^{\circ} 17.44^{\prime} \mathrm{W}\end{array}$ & 1 & 755 & $\begin{array}{c}0.19 \\
\pm 0.04\end{array}$ & $\begin{array}{l}2.88 \\
\pm 0.6\end{array}$ & $\begin{array}{c}0.5 \\
\pm 0.0\end{array}$ & $\begin{array}{l}79.7 \\
\pm 0.8\end{array}$ & $\begin{array}{r}19.1 \\
\pm 1.0\end{array}$ & $\begin{array}{c}1.2 \\
\pm 0.5\end{array}$ \\
\hline \multirow{3}{*}{  } & PS96-017 & $\begin{array}{l}4 \text { Jan. } \\
2016\end{array}$ & $\begin{array}{c}75^{\circ} 00.85^{\prime} \mathrm{S} \\
32^{\circ} 52.51^{\prime} \mathrm{W}\end{array}$ & 4 & 608 & $\begin{array}{c}0.06 \\
\pm 0.01 \\
\end{array}$ & $\begin{array}{c}0.83 \\
\pm 0.03 \\
\end{array}$ & $\begin{array}{c}0.2 \\
\pm 0.0\end{array}$ & $\begin{array}{l}43.4 \\
\pm 6.1\end{array}$ & $\begin{array}{l}49.1 \\
\pm 4.1\end{array}$ & $\begin{array}{c}7.5 \\
\pm 2.0\end{array}$ \\
\hline & PS96-026 & $\begin{array}{l}8 \text { Jan. } \\
2016\end{array}$ & $\begin{array}{l}75^{\circ} 15.10^{\prime} \mathrm{S} \\
37^{\circ} 54.85^{\prime} \mathrm{W}\end{array}$ & 1 & 415 & $\begin{array}{c}0.08 \\
\pm 0.06\end{array}$ & $\begin{array}{r}1.49 \\
\pm 1.1\end{array}$ & $\begin{array}{c}0.2 \\
\pm 0.1\end{array}$ & $\begin{array}{c}63.2 \\
\pm 19.2\end{array}$ & $\begin{array}{c}33.7 \\
\pm 16.3\end{array}$ & $\begin{array}{c}3.0 \\
\pm 2.9\end{array}$ \\
\hline & PS96-048 & $\begin{array}{c}18 \text { Jan. } \\
2016\end{array}$ & $\begin{array}{l}74^{\circ} 46.18^{\prime} \mathrm{S} \\
35^{\circ} 20.91^{\prime} \mathrm{W}\end{array}$ & 0 & 482 & $\begin{array}{c}0.15 \\
\pm 0.05\end{array}$ & $\begin{array}{r}2.14 \\
\pm 0.5\end{array}$ & $\begin{array}{c}0.3 \\
\pm 0.0\end{array}$ & $\begin{array}{l}66.8 \\
\pm 2.2\end{array}$ & $\begin{array}{r}30.3 \\
\pm 2.4\end{array}$ & $\begin{array}{c}2.9 \\
\pm 1.1\end{array}$ \\
\hline
\end{tabular}


Anobothrus material was deposited in the Zoologische Sammlung, Universität Rostock (ZSRO, Zoological collection of Rostock University). The catalogue numbers are given below.

There is continuing confusion about the numbering anterior to the paleal segment (Day 1964; Parapar et al. 2012). We follow the opinion that the second segment is considered as the paleal segment; therefore, uncini begin on segment 6 = thoracic chaetiger 5 (Annenkova 1930; Eliason 1955; Uschakov 1965; Cazaux 1982; Orrhage 2001; Reuscher et al. 2009). Here we include the paleal chaetiger in our counts of thoracic chaetigers (thoracic chaetiger 1), as described by Reuscher et al. (2009). Furthermore, we use the term "intermediate segments", as introduced by Imajima et al. (2012), for segments with neuropodia formed as tori (similar to those in thoracic uncinigers) but lacking notopodia and notochaetae. Therefore, these segments were excluded from the abdominal segment count. Fig. 1 shows a schematic overview of the terminology used and the counting of segments, chaetigers and uncinigers.

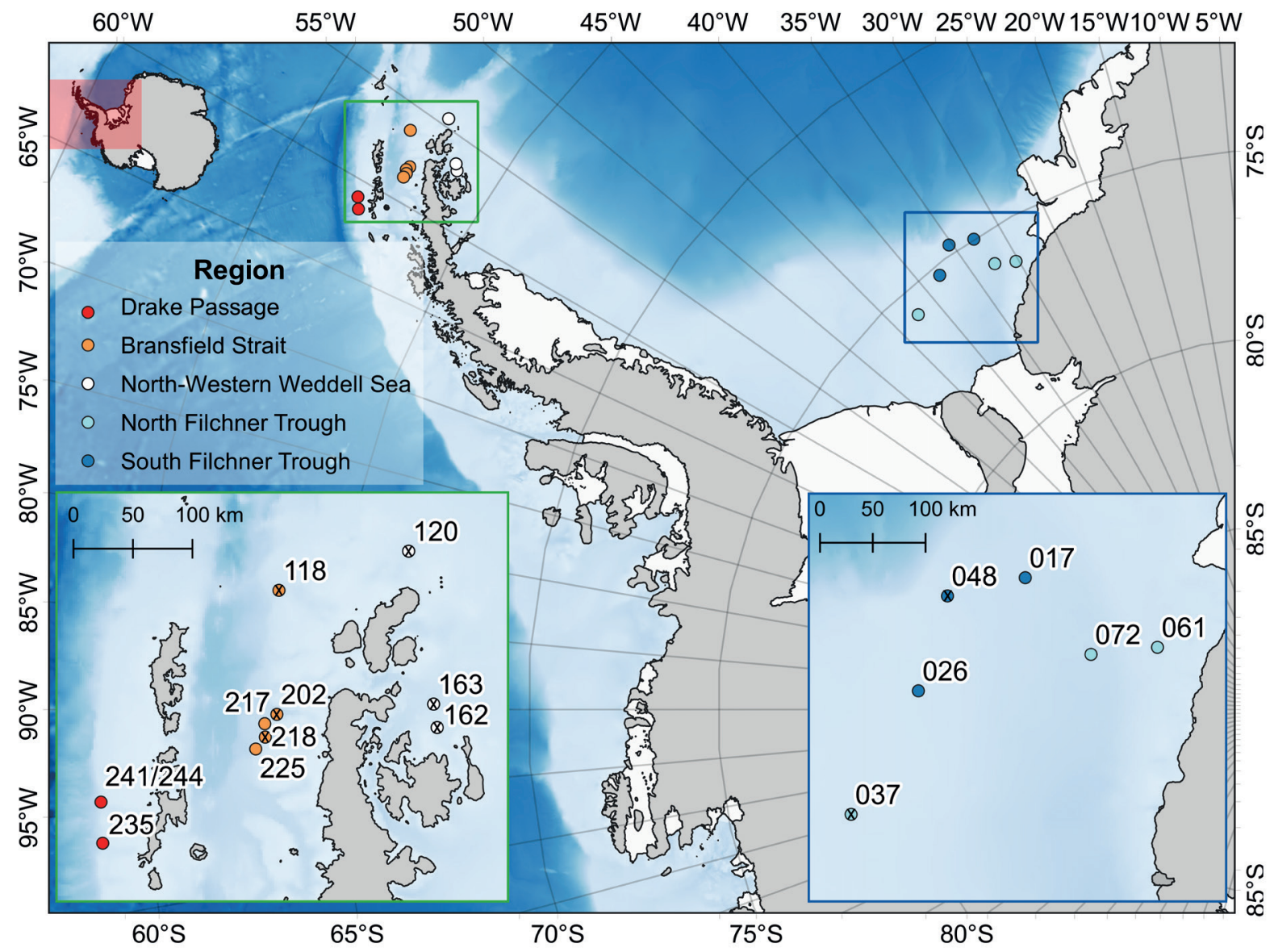

Fig. 2. Sampling stations in the vicinity of the Antarctic Peninsula during RV Polarstern expedition PS 81 (Drake Passage, Bransfield Strait, North-Western Weddell Sea, green frame) and the South-Eastern Weddell Sea during PS 96 (North Filchner Trough, South Filchner Trough, blue frame). Stations without Anobothrus konstantini Säring \& Bick sp. nov. labeled with a cross. Information about sampled stations and number of individuals of $A$. konstantini Säring \& Bick sp. nov. are given in Table 1. 


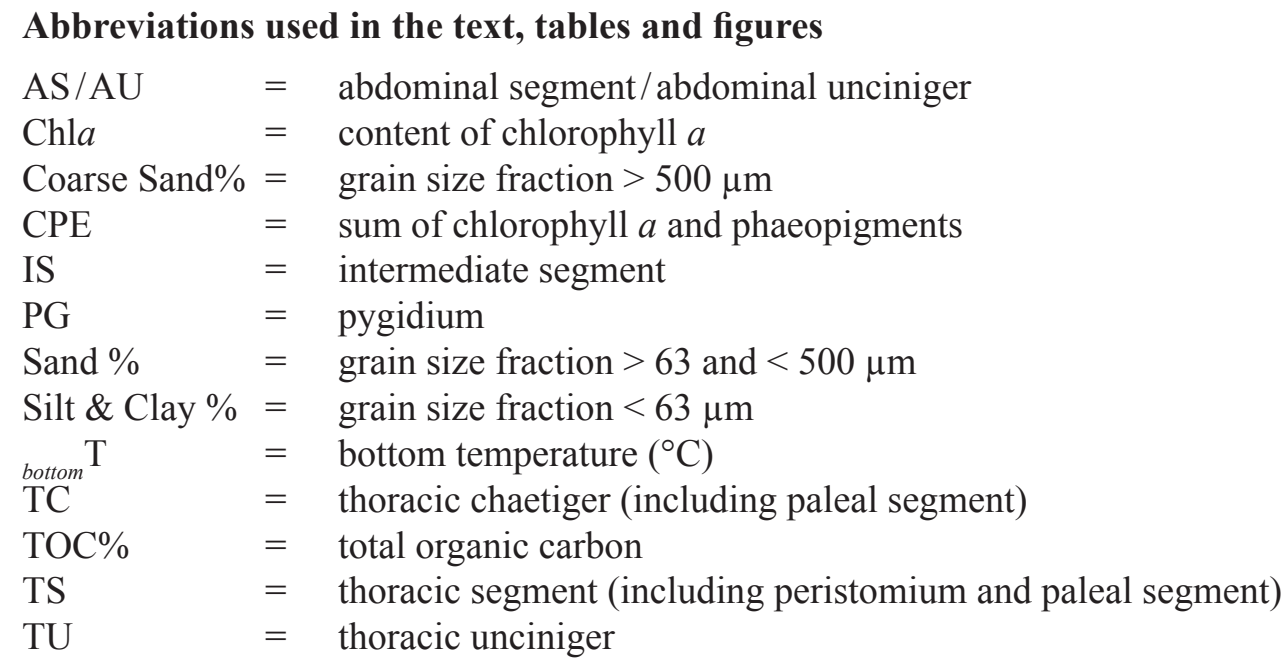

\section{Results}

Class Polychaeta Grube, 1850

Order Terebelliformia Levinsen, 1883

Ampharetidae Malmgren, 1866

Family Ampharetinae Chamberlin, 1919

Genus Anobothrus Levinsen, 1844

Sosanides Hartmann-Schröder, 1965: 243-246.

Anobothrella Hartman, 1967: 155-156.

Melythasides Desbruyères, 1978: 232-246.

\section{Type species}

Ampharete gracilis Malmgren, 1866.

Generic diagnosis (after Alalykina \& Polyakova (2020), Bonifácio et al. (2015), Imajima et al. (2013), Jirkov (2009) and Reuscher et al. (2009))

Prostomium trilobed, Ampharete-type (Jirkov 2009), without glandular ridges. Buccal tentacles smooth or papillose. Segments 2 and 3 can be fused; notochaetae on either segment 2 or 3 reduced, or developed in both segments. Three or four pairs of smooth or papillose branchiae; three pairs arising from segments 2-4 arranged in a transverse row, with or without a gap; fourth pair, if present, behind this row and originating from segment 5. A pair of median nephridial papillae, if present, behind branchiae. Chaetae on segment 2 present and developed as paleae, or absent. Notopodia and notochaetae on segment 3 may be reduced or present. 16-17 thoracic segments, 14-16 thoracic chaetigers, and 11 or 12 thoracic uncinigers starting at segment 6 . Notopodial cirri present or absent. Circular glandular band on thoracic unciniger 1, 2 or 3. Fourth-, fifth- or sixth-to-last thoracic unciniger with one, two or three modifications: elevated notopodia, a more or less pronounced glandular ridge between notopodia, and modified notochaetae. Subsequent thoracic uncinigers without modification but prolongated. One or two intermediate segments. Abdominal rudimentary notopodia absent. Pygidium with anus terminal, with or without numerous papillae, or with or without anal cirri.

\section{Remarks}

This generic diagnosis combines diagnoses proposed by Alalykina \& Polyakova (2020), Bonifácio et al. (2015), Imajima et al. (2013), Jirkov (2009) and Reuscher et al. (2009), and follows the terminology of 
counts used by Imajima et al. (2012, 2013) and Reuscher et al. (2009). Ampharetidae are usually known for a constant number of thoracic chaetigers and uncinigers for adult individuals (Reuscher et al. 2009; Stiller et al. 2020 for exclusion of Melinnidae).

Anobothrus konstantini Säring \& Bick sp. nov. urn:lsid:zoobank.org:act:6E3CCF0F-C510-4BA2-813A-CF43BDB4B744

Figs 3-6

\section{Diagnosis}

Four pairs of branchiae; three pairs in anterior transverse row with a small gap, and fourth pair posteriorly shifted, directly between innermost and middle branchiae of anterior row. Segment 6 (thoracic chaetiger 5 , thoracic unciniger 1) with circular glandular band. Segment 12 (thoracic chaetiger 11, thoracic unciniger 7) with elongated ridge between notopodia; modified notochaetae present. Segment 2 (thoracic chaetiger 1) with long and thin paleae, about 12-14 on each side. Sixteen thoracic segments (15 thoracic chaetigers, 11 thoracic uncinigers); 2 intermediate and 10 abdominal segments.

\section{Etymology}

This species is dedicated to the brother of the first author (FS), Konstantin Zülske, who will be always a special part of her life.

\section{Type Material}

\section{Holotype}

SOUTH-EASTERN WEDDELL SEA • body length $9.3 \mathrm{~mm}$; North Filchner Trough, PS96 exp., station $017-3$; 75 $00.85^{\prime} \mathrm{S}, 32^{\circ} 52.51^{\prime} \mathrm{W}$; depth $608.2 \mathrm{~m}$; 4 Jan. 2016; H. Link and G. Veit-Köhler leg.; multicorer; ZSRO-P2655.

\section{Paratypes}

SOUTH-EASTERN WEDDELL SEA • 1 spec.; South Filchner Trough, PS96 exp., station 061-5; $76^{\circ} 05.93^{\prime} \mathrm{S}, 30^{\circ} 18.23^{\prime} \mathrm{W}$; depth $467.6 \mathrm{~m}$; 21 Jan. 2016; same collector and sampling as for holotype; ZSRO-P2660 • 1 spec.; South Filchner Trough, PS96 exp., station 072-9; 7551.37' S, 32¹7.44' W; depth $755.1 \mathrm{~m}$; 24 Jan. 2016; same collector and sampling as for preceding; used for SEM; ZSRO-P2661

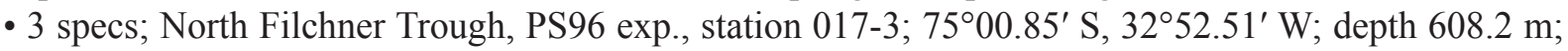
4 Jan. 2016; same collector and sampling as for preceding; ZSRO-P2662 1 spec.; North Filchner

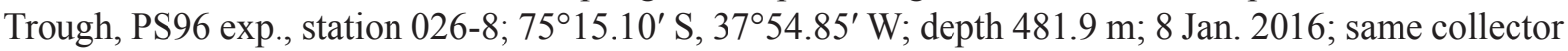
and sampling as for preceding; used for SEM; ZSRO-P2663.

\section{Additional Material}

ANTARCTIC PENINSULA • 1 spec.; Drake Passage, PS81 exp., station 235-2; 62 ${ }^{\circ} 6.60^{\prime}$ S, $60^{\circ} 36.50^{\prime}$ W; depth 355m; 7 Mar. 2013; H. Link leg; multicorer; ZSRO-P2656 • 1 spec.; Drake Passage, PS81 exp., station 241-5; $62^{\circ} 6.60^{\prime} \mathrm{S}, 60^{\circ} 36.50^{\prime} \mathrm{W}$; depth $403 \mathrm{~m}$; 9 Mar. 2013; same collector and sampling as for preceding; ZSRO-P2657 - 2 specs; Bransfield Strait, PS 81 exp., station $217-5$; $62^{\circ} 53.25^{\prime}$ S, $58^{\circ} 14.13^{\prime} \mathrm{W}$; depth $532 \mathrm{~m}$; 2 Mar. 2013; same collector and sampling as for preceding; one specimen used for micro-CT; ZSRO-P2658 - 1 spec.; Bransfield Strait, PS81 exp., station 225-2; 62 ${ }^{\circ} 56.08^{\prime}$ S, $58^{\circ} 40.76^{\prime} \mathrm{W}$; depth $543 \mathrm{~m}$; 4 Mar. 2013; same collector and sampling as for preceding; ZSRO-P2659.

\section{Description}

Complete specimens 7-13 mm long (holotype $9.3 \mathrm{~mm}$ ), and $0.5-0.8 \mathrm{~mm}$ wide (holotype $0.5 \mathrm{~mm}$ ) on thorax (Fig. 3D, compare Fig. 3A). 
16 thoracic segments (15 thoracic chaetigers, 11 thoracic uncinigers) (Fig. 1). Thorax wider and longer than abdomen, abdomen tapering posteriorly (compare Figs 3A, 4A). Continuous ventral shields on segments 2-12 (thoracic chaetigers 1-11). Median ventral groove from segment 13 (thoracic chaetiger 12) to pygidium.

Prostomium trilobed, anteriorly rounded, Ampharete-type (Jirkov 2009), without eye spots (compare Fig. 5B-C). Nuchal organs not observed. Buccal tentacles apparently smooth, observed for one specimen (ZSRO-P2662: paratype).

Four pairs of branchiophores; between two groups a small gap half as wide as branchiophores. Branchiae were lost on almost all specimens (11), one specimen with one outer gradually tapering papillose branchia (compare Figs 3A, 4A). First three pairs of branchiophores arranged in anterior transversal row (inner, middle and outer pairs), forming a high fold, originating from segments 2-4 (thoracic chaetigers 1-3), fourth pair of branchiae posteriorly shifted between innermost and middle branchiae of anterior row (Fig. 4F, compare Fig. 5A-B). Anterior end of branchiophores apparently fused together (Fig. 3D, compare Fig. 5A). Origin of branchiae not visible; nephridial papillae not visible.

Segment 2 (thoracic chaetiger 1) with 12-14 long, thin and slender paleae on each side, gradually tapering (holotype: left, 12 paleae plus a single small palea; right, 12 paleae plus a single small palea). Paleae protruding clearly beyond the prostomium (Fig. 3F, compare Fig. 4A), semicircularly arranged, with a small thin palea at the dorsal outer margin (compare Fig. 5B).
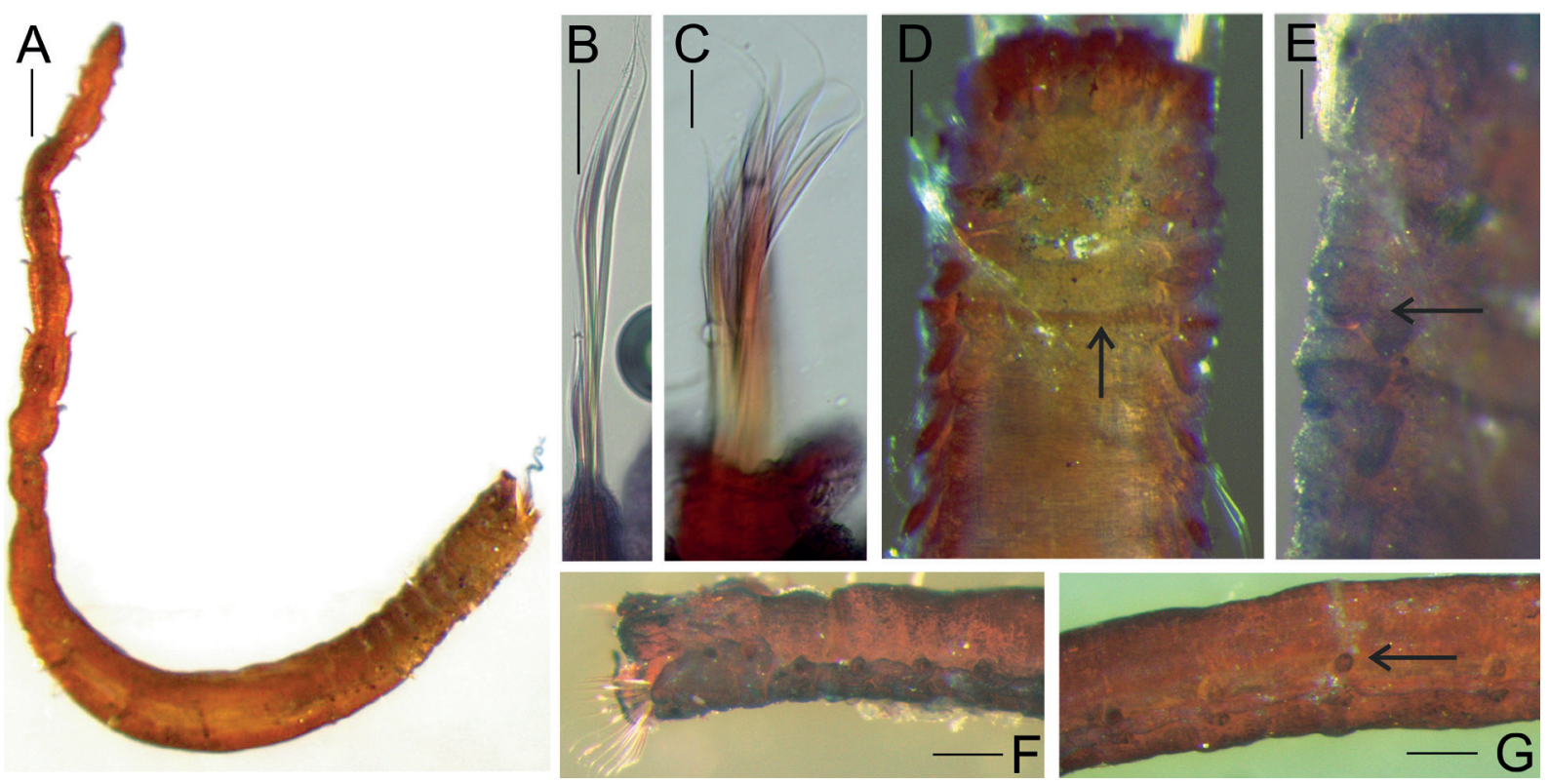

Fig. 3. Anobothrus konstantini Säring \& Bick sp. nov. Micrographs of ShirlastainA staining pattern. A. Complete specimen, lateral view with one outermost branchia, additional material (ZSRO-P2657). B. Notochaetae on segment 11 (TC 10), paratype (ZSRO-P2662). C. Modified notochaetae on segment 12 (TC 11, TC 7), paratype (ZSRO-P2660). D. Dorsal view of anterior end, arrow: glandular circular band on segment 6 (TC 5, TU 1), paratype (ZSRO-P2662). E. Lateral view, arrow: reduced neuropodium on segment 5 (TC 4), without uncini, paratype (ZSRO-P2662). F. Lateral view of anterior end, paratype (ZSRO-P2662). G. Lateral view of three thoracic segments, arrow: modified notopodium with dorsal ridge on segment 12 (TC 11, TU 7), paratype (ZSRO-P2662). Scale bars: $A=500 \mu \mathrm{m}$; B $=50 \mu \mathrm{m}$, $\mathrm{C}=20 \mu \mathrm{m} ; \mathrm{D}-\mathrm{E}=100 \mu \mathrm{m} ; \mathrm{F}-\mathrm{G}=200 \mu \mathrm{m}$. 
Notopodia from segment 3 (thoracic chaetiger 2), well developed with a simple elongated lobe, and with some capillary chaetae; first notopodium smaller than subsequent notopodia and slightly shifted dorsally (Figs 4F, 6A); notopodia without cirri or papillae. Eleven thoracic uncinigers, from segment 6 (thoracic chaetiger 5) to segment 16 (thoracic chaetiger 15) (Fig. 1, compare Fig. 4A).

Segment 6 (thoracic chaetiger 5, thoracic unciniger 1) with circular glandular band (Figs 3D, 4F, 6A-B). Notopodia of segment 12 (thoracic chaetiger 11, thoracic unciniger 7) elevated and connected by a pronounced dorsal ridge (Figs 3G, 6A, compare Fig. 4K), with ciliated band (Fig. 6C).

Two intermediate segments; notopodia absent but neuropodia of thoracic type present (Figs 4L, 6E). Abdomen with 10 segments (10 uncinigers); notopodia and -chaetae absent. Abdominal neuropodia as elongated pinnules without dorsal cirri (Fig. 6D).

Thoracic notochaetae bilimbate capillaries, tapering to slender tips (Figs 3B, 6F-H, compare Fig. 4BC); segment 3 (thoracic chaetiger 2) with 3-4 short notochaetae in a tuft; notochaetae of subsequent chaetigers arranged in two rows (Fig. 6F), anterior row with 3 shorter (compare Fig. 4C) and posterior row with 4 longer chaetae (compare Fig. 4B). Notochaetae of modified segment 12 (thoracic chaetiger 11, thoracic unciniger 7) tapered more abruptly toward the tip than regular notochaetae (Figs 3C, 6I, compare Fig 4D-E). Thoracic neuropodia with 17-21 uncini (holotype: thoracic segment 5 with 20 uncini, thoracic segments 10 and 16 with 17 uncini each) in one row. Thoracic uncini about $16 \mu \mathrm{m}$ long, pectinated, with 6-7 teeth in lateral view, above rostral tooth 3-4 teeth in a row, and about 6 teeth in apical row (compare Fig. 4G-H). Neuropodia of intermediate segments with 15-22 uncini (holotype: intermediate segment 2 with 16 uncini), and abdominal neuropodia with 16-19 uncini (holotype: abdominal segments 1,3 and 5 with 16 uncini each) in marginal position of pinnules. Abdominal uncini about $8 \mu \mathrm{m}$ long, pectinated, with 5-6 teeth in lateral view, above rostral tooth 7-8 teeth in a row, about 2 teeth in apical row (Fig. 6J-K, compare Fig. 4I-J). Number of uncini declines towards pygidium.

Pygidium with terminal anus, without cirri but papillose folds present (Fig. 6D).

Methyl blue staining pattern. Intensive staining of bases of noto- and neuropodia. Body uniformly spotted blue, without distinct pattern, but a circular glandular band on segment 6 (thoracic chaetiger 5, thoracic unciniger 1) becomes visible.

ShirLastainA staining Pattern. Staining pattern similar to methyl blue staining pattern (Fig. 3B-G, compare Fig. 3A), but additional structures are visible: the circular glandular band on segment 6 (thoracic chaetiger 5, thoracic unciniger 1) (Fig. 3D) and an elevated dorsal ridge on segment 12 (thoracic chaetiger 11, thoracic unciniger 7) (Fig. 3G).

\section{Biology}

Male gametes, about 9-10 $\mu \mathrm{m}$ in diameter, were observed in segments 4-11 (thoracic chaetigers 3-10) in one specimen, collected in January in the North Filchner Trough.

\section{Remarks}

The branchiae were lost in almost all specimens, branchiophores are apparently fused together and are not separated (compare Fig. 5B-D). Due to poor conservation, the segmental origin of branchiae could not be described in more detail. We suggest the following arrangement of branchiae of the anterior row: segment 2, branchiae in the middle position, segment 3 , branchiae of outermost position, segment 4 , innermost position, segment 5 , branchiae in posterior position between innermost and middle branchiae of anterior transverse row. 

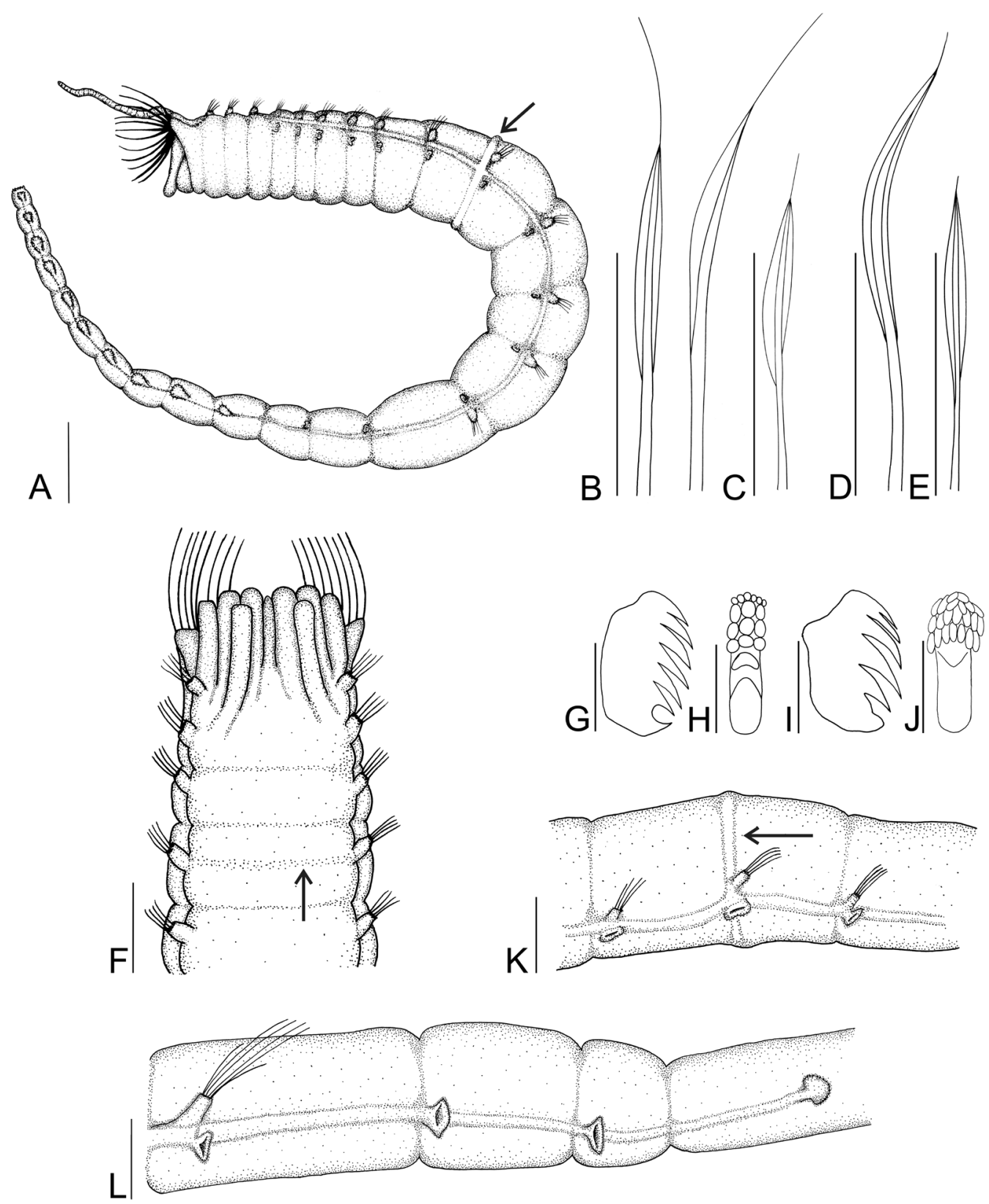

Fig. 4. Anobothrus konstantini Säring \& Bick sp. nov. A. Complete specimen with one outermost branchia, lateral view, arrow: dorsal ridge on segment 12 (TC 11, TU 7), additional material (ZSRO-P2657). B. Long thoracic notochaeta, additional material (ZSRO-P2658). C. Short thoracic notochaeta, additional material (ZSRO-P2658). D. Long notochaeta of the modified segment 12 (TC 11, TU 7), additional material (ZSRO-P2658). E. Short notochaeta of the modified segment 12 (TC 11, TU 7), additional material (ZSRO-P2658). F. Dorsal view of the anterior end, paratype (ZSRO-P2662). G. Lateral view of thoracic uncinus, additional material (ZSRO-P2658). H. Frontal view of thoracic uncinus, additional material (ZSRO-P2658). I. Lateral view of abdominal uncinus, additional material (ZSRO-P2658). J. Frontal view of abdominal uncinus, additional material (ZSRO-P2658). K. Lateral view of three thoracic segments, arrow: dorsal ridge on segment 12 (TC 11, TU 7) with slightly elevated notopodia, additional material (ZSRO-P2656). L. Lateral view of last thoracic, two intermediate and first abdominal segments, paratype (ZSRO-P2663). Scale bars: A $=500 \mu \mathrm{m} ; \mathrm{B}-\mathrm{E}=100 \mu \mathrm{m} ; \mathrm{F}, \mathrm{K}=200 \mu \mathrm{m}$; $\mathrm{G}-\mathrm{H}=10 \mu \mathrm{m} ; \mathrm{I}-\mathrm{J}=5 \mu \mathrm{m} ; \mathrm{L}=50 \mu \mathrm{m}$. 
The holotype and paratypes from the South-Eastern Weddell Sea did not show any significant differences in diagnostic characteristics. Specimens of the additional material showed only minor differences to the diagnosis of the holotype and paratypes. Therefore, the additional material was used for the light microscopy (Fig. 3A), drawing (Fig. 4A-E, G-K) and the micro-CT (Fig. 5). However, we found one modification of one specimen from the additional material (ZSRO-P2658) when analysing the images from the micro-CT: one pair of small and fine paleae next to the regular large and thin paleae (Fig. 5B, D). The small paleae are placed where newly formed chaetae are expected and may be a growing state (Tilic et al. 2015). However, the shape and form is different compared to the other paleae. The purpose of these paleae was not clearly clarified.

The presence of a reduced neuropodium on segment 5 (thoracic chaetiger 4) was presumed on one specimen using ShirlastainA because at the position of the thoracic neuropodia and of the same size as these, the same staining pattern was visible on this segment (Fig. 3E). However, uncini were not observed.
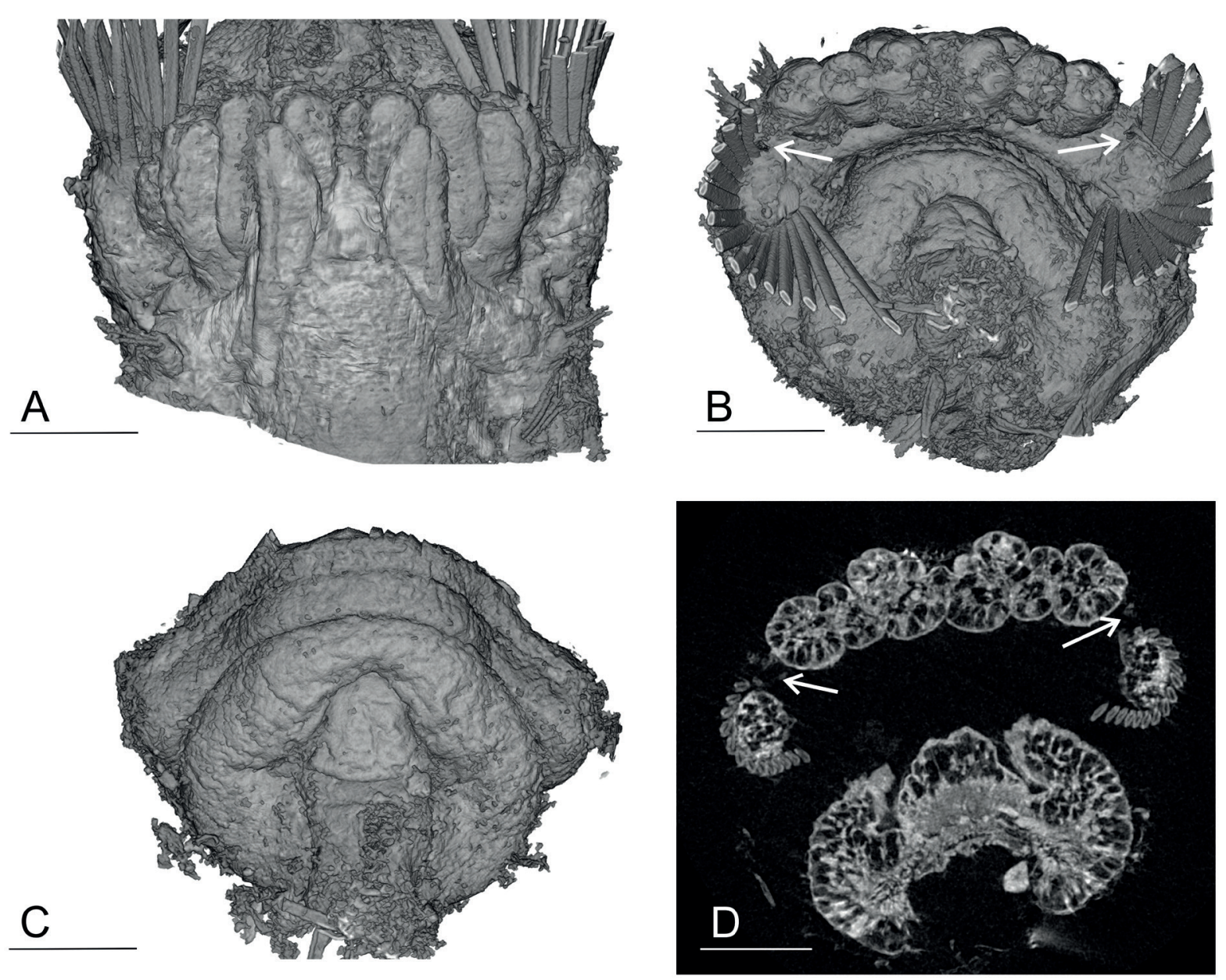

Fig. 5. Anobothrus konstantini Säring \& Bick sp. nov., additional material (ZSRO-P2658). Micro-CT graphs, additional material. A. Anterior end with arrangement of branchiae, dorsal view. B. Anterior end with arrangement of branchiae, frontal view (note semicircular arrangement of paleae; arrows: small paleae on each side). C. Frontal view of anterior end, without branchiae or paleae (note: Ampharete-type prostomium). D. Anterior end, transverse section of branchiae, paleae and prostomium (note arrows: small paleae on each side). Scale bars: A-D $=100 \mu \mathrm{m}$. 


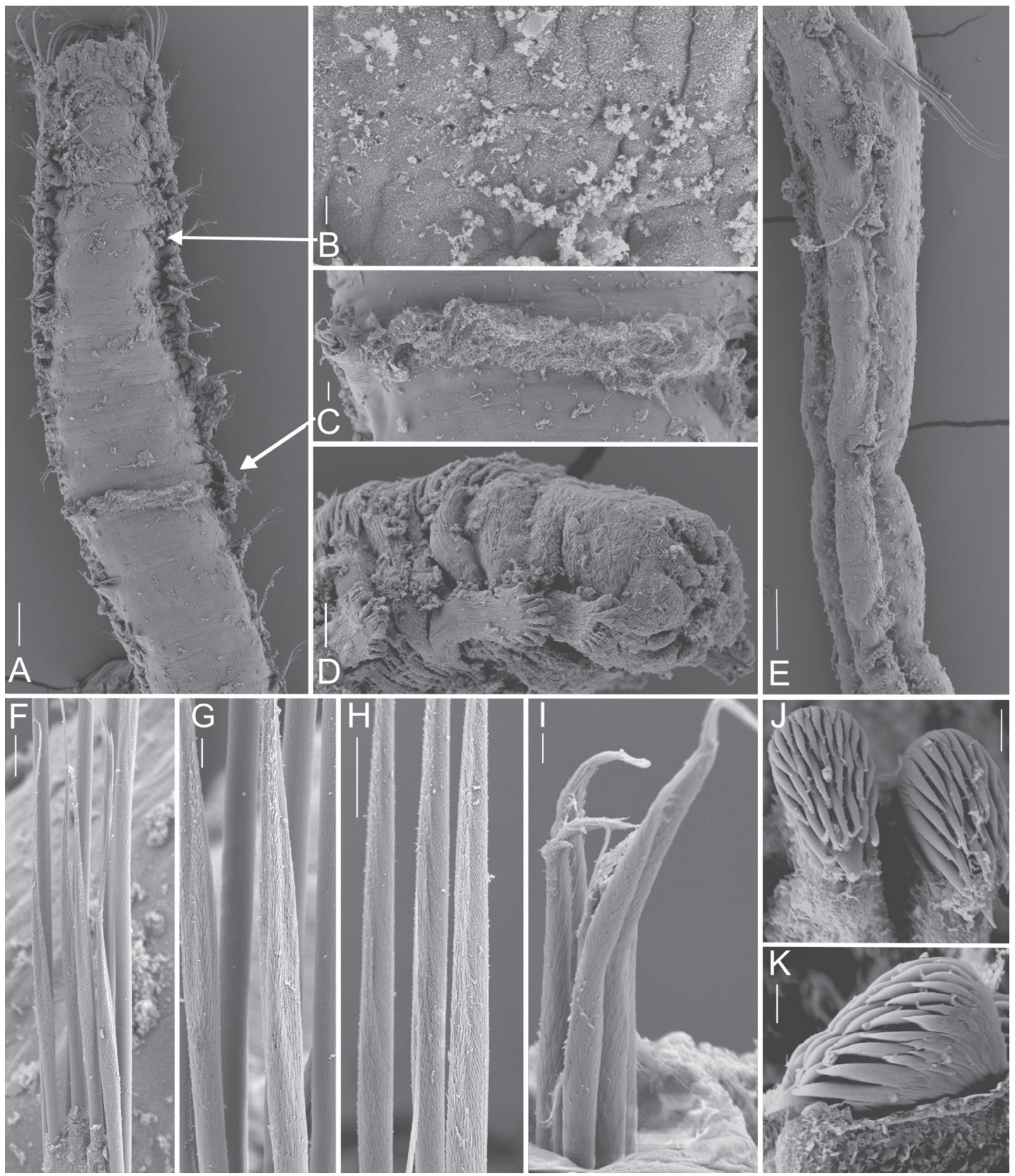

Fig. 6. Anobothrus konstantini Säring \& Bick sp. nov. SEM micrographs. A. Anterior end and thorax, dorsal view, arrows: segment 6 (thoracic chaetiger 5, thoracic unciniger 1) and segment 12 (TC 11, TU 7), paratype (ZSRO-P2661). B. Pores in glandular band on segment 6 (TC 5, TU 1), dorsal view, paratype (ZSRO-P2661). C. Elevated ridge with cilia on segment 12 (TC 11, TU 7), dorsal view, paratype (ZSRO-P2661). D. Posterior end with papillose pygidium, lateral view, paratype (ZSRO-P2663). E. Last thoracic, two intermediate and first abdominal segments, lateral view, paratype (ZSRO-P2663). F. 4 longer and 3 shorter notochaetae of notopodium on segment 15 (TC 14, TU 10), paratype (ZSRO-P2661). G. Margin of short notochaetae on segment 15 (TC 14, TU 10), paratype (ZSRO-P2661). H. Margin of long notochaetae on segment 15 (TC 14, TU 10), paratype (ZSRO-P2661). I. Modified notochaetae on segment 12 (TC 11, TU 7), paratype (ZSRO-P2661). J. Abdominal uncini on abdominal segment 8, frontal view, paratype (ZSRO-P2663). K. Abdominal uncinus on abdominal segment 8, lateral view, paratype (ZSRO-P2663). Scale bars: A, E $=100 \mu \mathrm{m} ; \mathrm{B}, \mathrm{I}=2 \mu \mathrm{m} ; \mathrm{C}, \mathrm{D}=20 \mu \mathrm{m} ; \mathrm{F}, \mathrm{H}=10 \mu \mathrm{m}$; $\mathrm{G}=3 \mu \mathrm{m}, \mathrm{J}-\mathrm{K}=1 \mu \mathrm{m}$. 
Uncini of the thoracic and intermediate neuropodia are about twice the size of uncini of the abdomen. A variation in size or shape of uncini along their row on a single neuropodium was not found.

Due to the fixation in $4 \%$ formaldehyde solution and the subsequent preservation in a $70 \%$ ethanol solution, no statement can be made about the pigmentation of fresh material.

Anobothrus konstantini Säring \& Bick sp. nov., A. bimaculatus Fauchald, 1972 and A. mancus Fauchald, 1972 differ from the other Anobothrus species with four pairs of branchiae and the presence of paleae, A. amourouxi Bonifácio, Lavesque, Bachelet \& Parapar, 2015, A. anatarctica Monro 1939, A. glandularis (Hartmann-Schröder, 1965), A. gracilis (Malmgren, 1866), A. mironovi Jirkov, 2009, A. paleatus Hilbig, 2000, A. paleaodiscus Schüller \& Jirkov, 2013, A. patagonicus (Kinberg, 1867), A. patersoni Jirkov, 2009, A. pseudoampharete Schüller, 2008, A. rubropaleatus Schüller \& Jirkov, 2013 and A. wilhelmi Schüller \& Jirkov, 2013, in having 11 instead of 12 thoracic uncinigers. Within this group, only A. paleatus has a glandular band with an elevated ridge on the fourth-to-last thoracic segment (thoracic segment 14, thoracic unciniger 9) the remaining eleven Anobothrus species, as well as A. konstantini Säring \& Bick sp. nov., show a modification of the fifth-to-last thoracic segment. However, due to the difference in the number of segments (12 thoracic uncinigers vs. 11 thoracic uncinigers), A. konstantini Säring \& Bick sp. nov. posseses this character on segment 12, whereas it is present on segment 13 in the previously mentioned species. In addition, the first transverse band on the anterior part of the thorax is not mentioned for A. pseudoampharete.

Anobothrus amourouxi, A. anatarctica, A. glandularis, A. gracilis, A. mironovi, A. paleatus, A. paleaodiscus and A. patersoni have a transversal band on segment 8, while A. rubropaleatus and A. wilhelmi have it on segment 7 . Only one species, A. patagonicus, possesses a transversal band on segment 6, as described for A. konstantini Säring \& Bick sp. nov. However, A. patagonicus differs from A. konstantini Säring \& Bick sp. nov. by the larger body length of about $19 \mathrm{~mm}$ and up to 30 uncini on neuropodia of segment 6, while the body length A. konstantini Säring \& Bick sp. nov. ranges between 7 and $13 \mathrm{~mm}$, with about 16-19 thoracic uncini on the neuropodia of segment 6 .

The only two species with paleae on segment 2 , four pairs of branchiae and 11 thoracic uncinigers are A. bimaculatus and A. mancus. However, A. bimaculatus is significantly larger (65 $\mathrm{mm})$, has eyespots and has modified notopodia on segment 11, instead of on segment 12 as in Anobothrus konstantini Säring \& Bick sp. nov. Anobothrus mancus is the only species with modified notopodia on segment 12 , but segments 3 and 4 are fused, and notopodia are absent on segment 3. Furthermore, A. mancus is missing the circular glandular band on segment 6 .

\section{Distribution}

The holotype and paratypes of Anobothrus konstantini Säring \& Bick sp. nov. were found in shelf regions in the South-Eastern Weddell Sea (North Filchner Trough and South Filchner Trough). The additional material was sampled from shelf regions of the Antarctic Peninsula, in the Drake Passage and Bransfield Strait (Fig. 2, Table 1).

\section{Ecology}

The type material of Anobothrus konstantini Säring \& Bick sp. nov. (1 holotype, 6 paratypes) was collected from soft sediments at water depths between 415 and $755 \mathrm{~m}$ from the South-Eastern Weddell Sea. This region is characterized by a high to constant ice cover and low ${ }_{\text {bottom }} \mathrm{T}$ (around $-1.9^{\circ} \mathrm{C}$, Säring et al. submitted: table 2; Schröder et al. 2016). The highest abundance was detected at one sampling site in the North Filchner Trough region (4 individuals per station), with low organic (TOC $0.2 \% \pm 0.0$ ) and the least fresh $\left(\mathrm{Chl} a=0.06 \mu \mathrm{g} \mathrm{g}^{-1} \pm 0.01\right)$ material on the seafloor. This sampling site is described by a low amount of silt \& clay (43.4\%) compared to the higher amount of sand (49.1\%). The remaining 
material (3 paratypes) was found at sites with higher silt \& clay $(>63.2 \%)$ and lower sand $(<33.7 \%)$ content, and low Chla concentrations $\left(<0.19 \mu \mathrm{g} \mathrm{g}^{-1}\right)$. Anobothrus konstantini Säring \& Bick sp. nov. occurs in a high variety of sediments, from fine mud to coarser sandy substrates in regions with low amount of fresh material on the seafloor.

The localities for the additional material sampled adjacent to the Antarctic Peninsula, Drake Passage (2 specimens) and Bransfield Strait (3 specimens), are known for no or a variable ice-cover and ${ }_{\text {bottom }} \mathrm{T}$ up to $0.5^{\circ} \mathrm{C}$ (Säring et al. submitted: table 2; Schröder et al. 2013). Nevertheless, these localities for the additional material show similar environmental conditions as the sampling sites of the type material: low Chla concentrations $\left(<0.31 \mu \mathrm{g} \mathrm{g}^{-1}\right)$ and TOC content $(<0.7 \%)$, and highly variable sediment substrates (Table 1).

Following the classification of functional traits by Jumars et al. (2015), A. konstantini Säring \& Bick sp. nov. is a hemi-sessile, tube-dwelling, subsurface deposit feeder.

\section{Key to all species of Anobothrus Levinsen, 1844}

The key accounts for the 23 species of Anobothrus Levinsen, 1844 considered valid, including the new species proposed here. It is modified after Bonifácio et al. (2015) and Alalykina \& Polyakova (2020).

1. Paleae absent

- Paleae present

2. Notochaetae always without hirsute tips; with circular band on thoracic unciniger 2

A. apaleatus Hilbig, 2000

- Notochaetae of modified notopodia with hirsute tips; without circular band on thoracic unciniger 2 A. fimbriatus Imajima, Reuscher \& Fiege, 2013

3. 3 pairs of branchiae in a transversal row, with or without gap 4

- 4 pairs of branchiae, one transversal row or anterior and posterior rows, with or without gap ....... 9

4. Branchiae with wide median gap A. dayi Imajima, Reuscher \& Fiege, 2013

- Branchiae without median gap 5

5. Segment 14 (thoracic unciniger 9) with elevated notopodia and notochaetae with hirsute tips A. flabelligerulus Imajima, Reuscher \& Fiege, 2013

- Segment 13 (thoracic unciniger 8) with elevated notopodia and notochaetae without modification 6

6. Two intermediate segments; segment 6 (thoracic unciniger 1) with circular band

A. auriculatus Alalykina \& Polyakova, 2020

- One intermediate segment, segment 7 or 8 (thoracic unciniger 2 or 3 ) with circular band

7. Segment 8 (thoracic unciniger 3 ) with circular band

A. jirkovi Alalykina \& Polyakova, 2020

- Segment 7 (thoracic unciniger 2) with circular band

8. Segments 2 and 3 (thoracic chaetigers 1 and 2) fused; without ventral fold; notopodia on segment 3 present; segment 5 (thoracic chaetiger 4) with one nephridial papilla dorsally

A. laubieri (Desbruyères, 1979)

- Segments 2 and 3 (thoracic chaetigers 1 and 2) fused; ventral fold with 8-12 rounded papillae; notopodia on segment 3 absent

A. sonne Alalykina \& Polyakova, 2020 


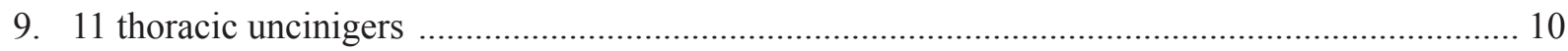

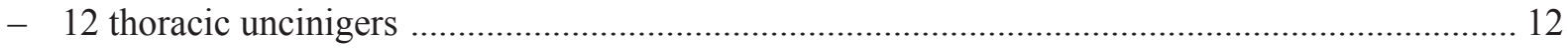

10. Segment 11 (thoracic unciniger 6) with modified notopodia; with eye spots

A. bimaculatus Fauchald, 1972

- Segment 12 (thoracic unciniger 7) with modified notopodia; without eye spots .............................11

11. Segment 6 (thoracic unciniger 1) with circular glandular band; notopodia with notochaetae present from segment 3

A. konstantini Säring \& Bick sp. nov.

- Segment 6 (thoracic unciniger 1) without circular glandular band; segments 3 and 4 fused; notopodia and notochaetae on segment 3 absent

A. mancus Fauchald, 1972

12. Modified notopodia on segment 14 (thoracic unciniger 9, fourth-to-last thoracic segment)

A. paleatus Hilbig, 2000

- Modified notopodia on segment 13 (thoracic unciniger 8, fifth-to-last thoracic segment) ............ 13

13. Segment 6,7 or 8 (thoracic unciniger 1, 2 or 3) without circular band; presumably dorsally shifted notopodia on segment 8 (thoracic unciniger 3 ); paleae abruptly to delicate tapering

A. pseudoampherete Schüller, 2008

- Segment 6,7 or 8 (thoracic unciniger 1,2 or 3) with circular band

14. Segment 6 (thoracic unciniger 1) with circular band

A. patagonicus (Kinberg, 1867)

- Segment 7 or 8 (thoracic unciniger 2 or 3 ) with circular band

15. Segment 7 (thoracic unciniger 2 ) with circular band

- Segment 8 (thoracic unciniger 3) with circular band

16. Branchiae arranged in transversal row; two outermost branchial pairs reduced in diameter compared to inner branchial pairs and positioned close to each other; paleae colorless, fine and more slender than notochaetae A. wilhelmi Schüller \& Jirkov, 2013

- First three pairs of branchiae arranged in anterior transversal row, fourth pair of branchiae posteriorly shifted between the two outermost branchiae of the anterior row; all branchiae with the same diameter; paleae stout, reddish, wider than notochaetae

A. rubropaleatus Schüller \& Jirkov, 2013

17. All notochaetae with hirsute tips

A. gracilis (Malmgren, 1866)

- Most notochaetae without hirsute tips; notochaetae of modified notopodia with or without hirsute tips

18. Modified notochaetae with hirsute tips

- Modified notochaetae without hirsute tips

19. 8-9 teeth on thoracic uncini in lateral view; diameter of all branchiophores almost same; paleae conspicuous, stout and long, originating from a prominent disc-like epidermal structure

A. paleaodiscus Schüller \& Jirkov, 2013

- 5 teeth on thoracic uncini in lateral view; inner and middle or posteriorly shifted pair of branchiophores half as thick and/or shorter than others; without prominent disc-like epidermal structure 20

20. First three pairs of branchiae arranged in anterior transversal row, fourth pair of branchiae posteriorly shifted between innermost and middle branchiae of the anterior row, fourth pair of 
branchiophores smaller and thinner than others and their branchiostyles several times shorter than others

- First three pairs of branchiae arranged in anterior transversal row, fourth pair of branchiae posteriorly shifted between innermost and middle branchiae of the anterior row, inner and middle pairs of branchiophores $2 / 3$ as long as and more slender than others

A. mironovi Jirkov, 2009

21. Segment 3 with notopodia and notochaetae; 16 thoracic chaetigers; surface of branchiostyles papillated; $4-5$ teeth on thoracic uncini in lateral view

- Segment 3 without or with reduced notopodia and without notochaetae; 15 thoracic chaetigers; more than 6 teeth on thoracic uncini in lateral view

22. Segment 3 (thoracic chaetiger 2) without notopodia; surface of branchiostyle smooth; 6 teeth on thoracic uncini in lateral view A. glandularis (Hartmann-Schröder, 1965)

- Segment 3 (thoracic chaetiger 2) with reduced notopodia, without notochaetae; surface of inner branchiostyle with transversal ciliated ridges; $6-7$ teeth on thoracic uncini in lateral view

A. amourouxi Bonifácio, Lavesque, Bachelet \& Parapar, 2015

\section{Discussion}

\section{Taxonomy}

All specimens of $A$. konstantini Säring \& Bick sp. nov. have 11 thoracic uncinigers starting at segment 6, two intermediate, and 10 abdominal segments. Only one individual has been observed with a neuropodium-like structure on segment 5 but without uncini (Fig. 3E). The reduced neuropodium was detected on both sides of this segment. All other characters were identical to the remaining eleven specimens. It is possible that these reduced neuropodia were an artefact, or that they were not visible in the other specimens due to poor conditions.

Additionally, three specimens with similar body shape and characters but with 12 , instead of 11 , thoracic uncinigers were found in the material studied but excluded here. These individuals have elevated notopodia with a dorsal ridge on the fifth-to last thoracic segment (thoracic unciniger 8) as it is described for A. patagonicus, but differ in the number of thoracic uncini: Anobothrus patatgonicus possesses up to 30 (Jirkov 2009) and the unidentified specimens 17-21. Due to poor conditions and damage to the anterior region we could neither verify a correct counting of segments nor a presence of a glandular band, or a fusion of segments 2 and 3 . These specimens can be described elsewhere when more individuals in better quality are available.

Species of Anobothrus have one or several modifications on the fourth-, fifth-, or sixth-to-last thoracic chaetigers: elevated notopodia and/or glandular ridge between notopodia and/or modified notochaetae. Anobothrus konstantini Säring \& Bick sp. nov. possesses these three characters on the fifth-to-last thoracic segment (segment 12, thoracic chaetiger 11, thoracic unciniger 7). Additionally, another glandular band was observed on segment 6 (thoracic chaetiger 5, thoracic unciniger 1) using ShirlastanA staining (Fig. 3D). This complete circular band on the anterior thorax of Anobothrus species is often not clearly visible (Jirkov 2009). Within Anobothrus this character is described as absent for A. fimbriatus Imajima, Reuscher \& Fiege, 2013 and $A$. dayi Imajima, Reuscher \& Fiege, 2013, and is not mentioned in the description for A. mancus and A. pseudoampherete. However, based on the illustration in Schüller (2008), a modification of the notopodia on segment 8 (thoracic unciniger 3 ) may be assumed for the latter species and possibly be a hint of a circular band. In the literature, this band was compared with those from Melinnampharete, Eusamythella and Neosamytha (Desbruyeres 1979; Holthe 1986). However, the band is developed as a dorsal ridge in Melinnampharete, Eusamythella and Neosamytha, while 
in Anobothrus it is completely circular (Jirkov 2009). Glandular pores of this band were found on the dorsal side using a scanning electron microscope (Fig. 6B).

SEM micrographs are important and commonly used to detect not only epidermal structures, like pores, but also other hard-to-see characters. It is especially useful for small specimens and individuals in poor condition. Only using SEM, two rows of notochaetae were found on all thoracic chaetigers except for segment 3 (thoracic chaetiger 2), an anterior row with 3 shorter and a posterior row with 4 longer chaetae. A similar arrangement of notochaetae has been described for other Anobothrus species, e.g., A. amourouxi and A. wilhelmi (Schüller \& Jirkov 2013; Bonifácio et al. 2015).

A micro-computed tomography (micro-CT) scanner can also be a useful tool for studying morphological characters (Faulwetter et al. 2013); three-dimensional imaging could give a boost to the development of virtual specimen collections, allowing rapid and simultaneous access to accurate virtual representations of type material. This paper explores the potential of micro-computed tomography (X-ray microtomography). In contrast to SEM, the advantage of micro-CT is that the examination of material is fast and gentle, the samples remain undamaged and are available for further investigations (Paterson et al. 2014). Micro-CT scanning is becoming a more widely used technique for the identification of new species, e.g., within the Trichobranchidae (Parapar \& Hutchings 2015; Parapar et al. 2016a, b), and Cossuridae (Parapar et al. 2018b). Within the Ampharetidae this technique has only been utilized to examine the internal anatomy of Ampharete santillani (Parapar et al. 2018a). We used micro-CT scanning to obtain a closer insight of the anterior end, and were able to describe the prostomium and the arrangement of the branchiae (compare Fig. 5A-D). These characters were not visible using SEM or light microscopy, due to the bad condition of the specimens. Furthermore, we observed small paleae on the outer edge of the semicircular arrangement of the paleae (compare Fig. 5B). We could not clarify the purpose of these small paleae, which differed in shape and size to the remaining paleae. One assumption may be a growing state, based on the place where new paleae are expected (Tilic et al. 2015). To increase the image quality and reduce the examination time we freeze-dried our sample and cut off the posterior part. Due to the low number of individuals and poor condition, we did not consider a second micro-CT scan for this study.

Terebelliformia, including Ampharetidae, is one of the most species-rich groups in Polychaeta, with around 1100 described species and a notable ecological and morphological diversity (Reuscher et al. 2012; Eilertsen et al. 2017; Horton et al. 2021).

In addition, currently generic relationships within the Ampharetidae and the relationships of species within a genus, such as in Anobothrus, have not yet been clarified (Reuscher et al. 2009). The morphological descriptions of Anobothrus species are challenging, due to the high variation of modifications and the presence of many morphologically similar, small-sized species. In recent years, genetic analysis has been a useful tool to identify many cryptic and pseudocryptic polychaete species and record a higher diversity than described by morphology alone (Nygren et al. 2018). In this study, we could not perform genetic analyses due to preservation in $4 \%$ formaldehyde solution. To still achieve a detailed and unambiguous description for quantitative aspects of this new species, we carried out a multidisciplinary approach: traditional light microscopy with methylene blue and ShirlastanA staining to identify macromorphology (e.g., appendages, glands, ciliary bands), SEM to detect micro-morphology (e.g., gland pores, structure of chaetae and uncini), and micro-CT for internal structures and external characters (e.g., paleae, branchial arrangement).

\section{Distribution and ecology}

A total of twelve individuals was found from the sampled shelf regions (355-755 m depth), whereas seven belong to the type material of Anobothrus konstantini Säring \& Bick sp. nov., from the South- 
Eastern Weddell Sea (415-755 $\mathrm{m}$ depth). This region is known as a high Antarctic region with a high and constant ice cover, low ${ }_{\text {bottom }} \mathrm{T}$ and low input of fresh material. The remaining 5 specimens (additional material) are reported from the shelf regions around the Antarctic Peninsula (Drake Passage, Bransfield Strait, 355-543 m depth), with none or variable ice-cover and higher ${ }_{\text {bottom }} \mathrm{T}$. However, the specimens from sampling sites around the Antarctic Peninsula and South-Eastern Weddell Sea showed only minor morphological differences. Based on current knowledge, most Anobothrus species are reported from the Pacific Ocean (14 species), six of which are known only from bathyal to hadal depths (Alalykina \& Polyakova 2020; Imajima et al. 2013; Jirkov 2009). The most common and widespread species, A. gracilis, as well as A. dayi, A. glandularis, A. flabelligerulus Imajima, Reuscher \& Fiege, 2013, A. mancus and A. paleatus, are found in shelf waters in the Pacific (Fauchald 1972; Hilbig et al. 2000; Jirkov 2009; Imajima et al. 2013), whereas A. amourouxi was described from the North Eastern Atlantic (Bonifácio et al. 2015). A total of five species of Anobothrus, including A. konstantini Säring \& Bick sp. nov., are known from the Southern Ocean. Anobothrus paleaodiscus from East Antarctica, as well as $A$. pseudoampharete and $A$. wilhelmi from the Weddell Sea, seem to be distributed in bathyal-abyssal depths (1047-4720 m) (Schüller 2008; Schüller \& Jirkov 2013), while A. antarctica is known from the circumantarctic water bodies (175-2060 m) (Jirkov 2009), and A. konstantini Säring \& Bick sp. nov. so far only from the shelf region.

However, nothing is known about the habitat of the species of Anobothrus in terms of grain size or food availability parameters so far. We found no specimens of A. konstantini Säring \& Bick sp. nov. at sites with higher fresh food input (Chla) and organic carbon (TOC), such as in the northwestern Weddell Sea, or in predominantly silty sediments (Table 1). Only general functional traits of Ampharetidae are known from the literature (Jumars et al. 2015: supplemental table A). According to this information, all genera within the Ampharetidae are characterized as discretely motile, tube-dwelling, surface-deposit feeders that use their tentacles to feed on microorganisms and particles. Combined with information on its general functional traits, we can assume that $A$. konstantini Säring \& Bick sp. nov. has a preferred habitat with lower silt and higher sand content in the sediment and a lower content of fresh detritus on the surface of the sediment in the Southern Ocean.

This study is part of a larger ecological study (Säring et al. submitted) with a set of different environmental parameters, in which 857 polychaetes from 31 families were collected. Thirty-nine specimens were identified as Ampharetidae (4.5\%), twelve of which belong to Anobothrus konstantini Säring \& Bick sp. nov. It seems that the Ampharetidae have a somewhat opposite distribution to that of other deposit feeders, such as Maldanidae and Paraonidae, which are mostly subsurface feeders and are very abundant in the North-Western Weddell Sea, whereas they are less abundant in the other four regions (Säring et al. in prep.).

Combining taxonomic studies with the quantitative description of environmental parameters and/or functional traits can contribute to a better understanding of species distribution and provide the basis for species distribution modeling (e.g., Meißner et al. 2014). Most species descriptions, especially for small invertebrates, only include information on depth range and geographic distribution. Describing a new species including quantitative information about its habitat, as we do here, allows quantitative relationship analysis and can be used to predict species distributions in hard-to-reach regions or for changing habitats such as those expected in the Southern Ocean (Jansen et al. 2018).

\section{Acknowledgments}

We acknowledge the crew of FS Polarstern and the lead scientists Julian Gutt (PS 81) and Michael Schröder (PS 96, both AWI) for the opportunity to take samples on board. Yasemin Bodur, Gritta VeitKöhler (Senckenberg am Meer) and Dieter Piepenburg helped with logistics and sampling during the cruises. We thank Derya Seifert for sorting the samples. We are grateful to Stefan Scholz (Department 
of Zoology, Rostock University), who prepared the specimens for SEM and took the micrographs on the micro-CT. Frank Springer (Electron Microscopic Centre of the Medical Faculty, Rostock University) is thanked for assisting with the SEM. We thank Anna Dietrich (Institute for Applied Ecosytem Research, Broderstorf) for helping with the microscope photographs. Igor Jirkov (Lomonosov Moscow State University), Julio Parapar (University A Coruña, Spain) and Michael Reuscher (EcoAnalysts, Inc., Moscow, ID, USA) kindly helped with uncertainties about the genera. Also, comments by two anonymous reviewers and editing by the editors of the European Journal of Taxonomy improved this manuscript. The micro-CT machine (DFG INST 264/130-1 FUGG) was jointly sponsored by the German Research Foundation (DFG) and the Land Mecklenburg-Vorpommern. This present work was funded by DFG SPP 1158 Antarctic Research Grants (LI 2313/6-1 and VE 260/10-1). Support was given by the Alfred Wegener Institute, Helmholtz-Centre for Polar and Marine Research (Polarstern cruise grants AWI_PS81_03,AWI_PS96_02).

\section{References}

Alalykina I.L. \& Polyakova N.E. 2020. New deep-sea species of Anobothrus (Annelida: Ampharetidae) from the Kuril-Kamchatka Trench and adjacent abyssal regions. Progress in Oceanography 182: e102237. https://doi.org/10.1016/j.pocean.2019.102237

Annenkova N.P. 1930. The fresh-water and brackish water Polychaeta of the U.S.S.R. Opredeliteli Organizmov presnykh Vod S.S.S.R. a presnovadnaya Fauna 2: 1-48. [In Russian]

Bonifácio P., Lavesque N., Bachelet G. \& Parapar J. 2015. Anobothrus amourouxi sp. nov., a new species of Ampharetidae (Polychaeta) from the Capbreton Canyon (Bay of Biscay, NE Atlantic Ocean). Journal of the Marine Biological Association of the United Kingdom 95: 961-969.

https://doi.org/10.1017/S0025315414002094

Cazaux C. 1982. Développement larvaire de l'Ampharetidae lagunaire Alkmaria romijni Horst 1919. Cahiers de Biologie marine 23: 143-157.

Chamberlin R.V. 1919. The Annelida Polychaeta. Memoirs of the Museum of Comparative Zoology at Harvard College 48: 1-514. Available from https://www.biodiversitylibrary.org/page/4369136 [accessed 24 Jan. 2022].

Clarke A. \& Johnston N.M. 2003. Antarctic marine benthic diversity. Oceanography and Marine Biology 41: 41-114.

Day J.H. 1964. A review of the family Ampharetidae (Polychaeta). Annals of the South African Museum 48: $97-120$.

Desbruyeres D. 1979. Melythasides laubieri gen. sp. nov. Ampharetidae (Annélides Polychètes sédentaires) abyssal de la mer de Norvège. Bulletin du Muséum national d'Histoire naturelle 353: 231-238.

Grube A. E. 1850. Die Familien der Anneliden. Archiv für Naturgeschichte, Berlin 16 (1): 249-364.

Eilertsen M.H., Kongsrud J.A., Alvestad T., Stiller J., Rouse G.W. \& Rapp H.T. 2017. Do ampharetids take sedimented steps between vents and seeps? Phylogeny and habitat-use of Ampharetidae (Annelida, Terebelliformia) in chemosynthesis-based ecosystems. BMC Evolutionary Biology 17: 1-15. https://doi.org/10.1186/s12862-017-1065-1

Eliason A. 1955. Neue oder wenig bekannte schwedische Ampharetiden (Polychaeta). Göteborgs Kungliga Vetenskaps-och Vitterhetssamhälles Handlingar B 6 (16): 1-17.

Fauchald K. 1972. Benthic polychaetous annelids from deep water off western Mexico and adjacent areas in the Eastern Pacific Ocean. Allan Hancock Monographs in Marine Biology: 1-575. 
Fauchald K. 1977. The polychaete worms. Definitions and keys to the orders, families and genera. Natural History Museum of Los Angeles County, Science Series 28: 1-188.

Faulwetter S., Vasileiadou A., Kouratoras M., Dailianis T. \& Arvanitidis C. 2013. Micro-computed tomography: Introducing new dimensions to taxonomy. ZooKeys 263: 1-45.

https://doi.org/10.3897/zookeys.263.4261

Gutt J. 2013. The Expedition of the Research Vessel "Polarstern" to the Antarctic in 2013 (ANTXXIX/3). Berichte zur Polar-und Meeresforschung 665. Alfred Wegener Institute, Helmholtz Centre for Polar and Marine Research, Bremerhaven.

Gutt J., Isla E., Bertler N.A., Bodeker G.E., Bracegirdle T., Cavanagh R.D., Comiso J.C., Convey P., Cummings V., DeConto R., De Master D., di Prisco G., d‘Ovidio F., Griffiths H.J., KhanA., López-Martinez J., Murray A.E., Nielsen U., Ott S., Post A., Ropert-Coudert Y., Saucède T., Scherer R., Schiaparelli S., Schloss I.R., Smith C., Stefels J., Stevens C., Strugnell J., Trimborn S., Verde C., Verleyen E., Wall D., Wilson N. \& Xavier J. 2018. Cross-disciplinarity in the advance of Antarctic ecosystem research. Marine Genomics 37: 1-17. https://doi.org/10.1016/j.margen.2017.09.006

Hartmann-Schröder G. 1965. Zur Kenntnis des Sublitorals der chilenischen Küste unter besonderer Berücksichtigung der Polychaeten und Ostracoden. II. Die Polychaeten des Sublitorals. Mitteilungen aus dem Hamburgischen zoologischen Museum und Institut 62, Supplement: 59-305.

Hilbig B. 2000. 8. Family Ampharetidae Malmgren, 1867. In: Blake J.A., Hilbig B. \& Scott P.V. (eds) Taxonomic Atlas of the Benthic Fauna of the Santa Maria Basin and Western Santa Barbara Channel, Volume 7. The Annelida Part 4. Polychaeta: Flabelligeridae to Sternaspidae: 169-230. Santa Barbara Museum of Natural History, Santa Barbara, California.

Holthe T. 1986. Polychaeta Terebellomorpha from the Northern Norwegian Sea and the Polar Sea, with descriptions of Mugga bathyalis sp. n. and Ymerana pteropoda gen. and sp. n. Sarsia 71: 227-234. https://doi.org/10.1080/00364827.1986.10419692

Imajima M., Reuscher M.G. \& Fiege D. 2012. Ampharetidae (Annelida: Polychaeta) from Japan. Part I: The genus Ampharete Malmgren, 1866, along with a discussion of several taxonomic characters of the family and the introduction of a new identification tool. Zootaxa 3490: 75-88.

Imajima M., Reuscher M.G. \& Fiege D. 2013. Ampharetidae (Annelida: Polychaeta) from Japan. Part II: Genera with elevated and modified notopodia. Zootaxa 3647: 137-166.

https://doi.org/10.11646/zootaxa.3647.1.7

Jansen J., Hill N.A., Dunstan P.K., Eléaume M.P. \& Johnson C.R. 2018. Taxonomic resolution, functional traits, and the influence of species groupings on mapping Antarctic seafloor biodiversity. Frontiers in Ecology and Evolution 6: 1-10. https://doi.org/10.3389/fevo.2018.00081

Jirkov I.A. 2009. Revision of Ampharetidae (Polychaeta) with modified thoracic notopodia. Invertebrate Zoology 5: 111-132. https://doi.org/10.15298/invertzool.05.2.03

Jirkov I.A. 2011. Discussion of taxonomic characters and classification of Ampharetidae (Polychaeta). Italian Journal of Zoology 78: 78-94. https://doi.org/10.1080/11250003.2011.617216

Johnston G. 1846. An index to the British Annelides. Annals and Magazine of Natural History 1: 433462.

Jumars P.A., Dorgan K.M. \& Lindsay S.M. 2015. Diet of worms emended: An update of polychaete feeding guilds. Annual Review of Marine Science 7: 497-520.

https://doi.org/10.1146/annurev-marine-010814-020007

Kinberg J.G.H. 1867. Annulata nova. Öfversigt af Kungliga Vetenskapsakademiens Förhandlingar, Stockholm 23 (9): 337-357. 
Levinsen, G.M.R. 1884. Systematisk-geografisk Oversigt over de nordiske Annulata, Gephyrea, Chaetognathi og Balanoglossi. Videnskabelige Meddelelser fra Dansk naturhistorisk Forening $i$ Köbenhavn 45 (1883): 92-350.

Malmgren A.J. 1866. Nordiska Hafs-Annulater. Öfversigt af Kungliga Vetenskapsakademiens Förhandlingar, Stockholm 22: 355-410.

Meißner K., Fiorentino D., Schnurr S., Martinez Arbizu P., Huettmann F., Holst S., Brix S. \& Svavarsson J. 2014. Distribution of benthic marine invertebrates at northern latitudes - An evaluation applying multi-algorithm species distribution models. Journal of Sea Research 85: 241-254.

https://doi.org/10.1016/j.seares.2013.05.007

Monro C.C.A. 1939. Polychaeta. Antarctic Research Expedition Reports, Series B, Zoology and Botany 4 (4): 87-156.

Nygren A., Parapar J., Pons J., Meißner K., Bakken T., Kongsrud J.A., Oug E., Gaeva D., Sikorski A., Johansen R.A., Hutchings P.A., Lavesque N. \& Capa M. 2018. A mega-cryptic species complex hidden among one of the most common annelids in the north east Atlantic. PLoS ONE 13 (6): e0198356. https://doi.org/10.1371/journal.pone.0198356

Orrhage L. 2001. On the anatomy of the central nervous system and the morphological value of the anterior end appendages of Ampharetidae, Pectinariidae and Terebellidae (Polychaeta). Acta Zoologica 82: 57-71. https://doi.org/10.1046/j.1463-6395.2001.00070.x

Parapar J. \& Hutchings P.A. 2015. Redescription of Terebellides stroemii (Polychaeta, Trichobranchidae) and designation of a neotype. Journal of the Marine Biological Association of the United Kingdom 95: 323-337. https://doi.org/10.1017/S0025315414000903

Parapar J., Helgason G.V., Jirkov I. \& Moreira J. 2012. Polychaetes of the genus Ampharete (Polychaeta: Ampharetidae) collected in Icelandic waters during the BIOICE project. Helgoland Marine Research 66: 331-344. https://doi.org/10.1007/s10152-011-0274-z

Parapar J., Moreira J., Gil J. \& Martin D. 2016a. A new species of the genus Terebellides (Polychaeta, Trichobranchidae) from the Iranian coast. Zootaxa 4117 (3): 321-340.

https://doi.org/10.11646/zootaxa.4117.3.2

Parapar J., Moreira J. \& O'Reilly M. 2016b. A new species of Terebellides (Polychaeta: Trichobranchidae) from Scottish waters with an insight into branchial morphology. Marine Biodiversity 46: 211-225. https://doi.org/10.1007/s12526-015-0353-5

Parapar J., Kongsrud J.A., Kongshavn K., Alvestad T., Aneiros F. \& Moreira J. 2018a. A new species of Ampharete (Annelida: Ampharetidae) from the NW Iberian Peninsula, with a synoptic table comparing NE Atlantic species of the genus. Zoological Journal of the Linnean Society 183: 526-555. https://doi.org/10.1093/zoolinnean/zlx077

Parapar J., Zhadan A., Tzetlin A., Vortsepneva E. \& Moreira J. 2018b. Exploring the anatomy of Cossura pygodactylata Jones, 1956 (Annelida, Cossuridae) using micro-computed tomography, with special emphasis on gut architecture. Marine Biodiversity 48: 751-761.

https://doi.org/10.1007/s12526-018-0873-x

Paterson G.L.J., Sykes D., Faulwetter S., Merk R., Ahmed F., Hawkins L.E., Dinley J., Ball A.D. \& Arvanitidis C. 2014. The pros and cons of using micro-computed tomography in gross and microanatomical assessments of polychaetous annelids. Memoirs of Museum Victoria 71: 237-246. https://doi.org/10.24199/j.mmv.2014.71.18 
Reuscher M., Fiege D. \& Wehe T. 2009. Four new species of Ampharetidae (Annelida: Polychaeta) from Pacific hot vents and cold seeps, with a key and synoptic table of characters for all genera. Zootaxa 2191: $1-40$.

Reuscher M., Fiege D. \& Wehe T. 2012. Terebellomorph polychaetes from hydrothermal vents and cold seeps with the description of two new species of Terebellidae (Annelida: Polychaeta) representing the first records of the family from deep-sea vents. Journal of the Marine Biological Association of the United Kingdom 92: 997-1012. https://doi.org/10.1017/S0025315411000658

Russell D.E. 1987. Paedampharete acutiseries, a new genus and species of Ampharetidae (Polychaeta) from the North Atlantic Hebble area, exibiting progenesis and broad intraspecific variation. Bulletin of the Biological Society of Washington 7: 140-151.

Säring F., Veit-Köhler G., Behrend B., Seifert D., Liskow I. \& Link H. 2021a. Sediment characteristics (Chla, Phaeo, TOC, TN, $\delta 13 \mathrm{C}, \delta 15 \mathrm{~N}$, grain size) at stations in the Weddell Sea (POLARSTERN cruise PS 96, ANT-XXXI/2, December 2015-February 2016). PANGAEA.

https://doi.pangaea.de/10.1594/PANGAEA.932718

Säring F., Link H. Behrend B., Bodur Y., Liskow I. \& Veit-Köhler G. 2021b. Biotic and abiotic watercolumn characteristics (Chla, Phaeo, TC, TN, $\delta 13 \mathrm{C}, \delta 15 \mathrm{~N}$ ) at stations in the Weddell Sea (POLARSTERN cruise PS 96, ANT-XXXI/2, December 2015-February 2016). PANGAEA.

https://doi.pangaea.de/10.1594/PANGAEA.932762

Säring F., Veit-Köhler G., Seifert D., Liskow I. \& Link H. submitted. Sea-ice related environmental drivers affect meio- and macrofauna communities differently at large scales (Southern Ocean, Antarctica). Marine Ecology Progress Series.

Schröder M. 2016. The Expedtion PS96 of the Research Vessel POLARSTERN to the southern Weddell Sea in 2015/2016. Berichte zur Porlar- und Meeresforschung 700. Alfred Wegener Institute, Helmholtz Centre for Polar and Marine Research, Bremerhaven. Available from https://epic.awi.de/id/eprint/41156/ [accessed 24 Jan. 2022].

Schröder M., Wisotzki A. \& van Caspel M. 2013. Physical oceanography measured on water bottle samples during POLARSTERN cruise ANT-XXIX/3. Alfred Wegener Institute, Helmholtz Center for Polar and Marine Research, Bremerhaven, PANGAEA. https://doi.org/10.1594/PANGAEA.811818

Schröder M., Ryan S. \& Wisotzki A. 2016. Physical oceanography during POLARSTERN cruise PS96 (ANT-XXXI/2 FROSN). Alfred Wegener Institute, Helmholtz Centre for Polar and Marine Research, Bremerhaven. PANGAEA. https://doi.org/10.1594/PANGAEA.859035

Schüller M. 2008. New polychaete species collected during the expeditions ANDEEP I, II, and III to the deep Atlantic sector of the Southern Ocean in the austral summers 2002 and 2005 - Ampharetidae, Opheliidae, and Scalibregmatidae. Zootaxa 1705 (1): 51-68. https://doi.org/10.11646/zootaxa.1705.1.4

Schüller M. \& Ebbe B. 2007. Global distributional patterns of selected deep-sea Polychaeta (Annelida) from the Southern Ocean. Deep-Sea Research Part II: Topical Studies in Oceanography 54: 17371751. https://doi.org/10.1016/j.dsr2.2007.07.005

Schüller M. \& Ebbe B. 2014. Chapter 5.13. Polychaetes. In: De Broyer C., Koubbi P., Griffiths H.J., Raymond B., d'Udekem d'Acoz C., van de Putte A., Danis B., David B., Grant S., Gutt J., Held C., Hosie G., Huettmann F., Post A. \& Ropert-Coudert Y. (eds). Biogeographic Atlas of the Southern Ocean. Scientific Committee on Antarctic Research: 134-137. Cambridge, UK.

Schüller M. \& Jirkov I.A. 2013. New Ampharetidae (Polychaeta) from the deep Southern Ocean and shallow Patagonian waters. Zootaxa 3692 (1): 204-237. https://doi.org/10.11646/zootaxa.3692.1.11 
Stiller J., Tilic E., Rousset V., Pleijel F. \& Rouse G.W. 2020. Spaghetti to a tree: A robust phylogeny for Terebelliformia (Annelida) based on transcriptomes, molecular and morphological data. Biology 9 (4): 1-28. https://doi.org/10.3390/biology9040073

Tilic E., Lehrke J. \& Bartolomaeus T. 2015. Homology and evolution of the chaetae in Echiura (Annelida). PLoS ONE 10 (3): e0120002. https://doi.org/10.1371/journal.pone.0120002

Uschakov P.V. 1965. Polychaeta of the Far Eastern Seas of the U.S.S.R. Keys to the Fauna of the U.S.S.R.: 1-419. Zoological Institute, Academy of Sciences U.S.S.R., 56. Israel Program for Scientific Translations, Jerusalem.

Vanreusel A., Hauquier F., Beuselinck B., Van Gansbeke D. Viaene N. \& Veit-Köhler G. 2021a. Abiotic and biotic sediment characteristics for stations from the North-Western Weddell Sea, Bransfield Strait, and Drake Passage (POLARSTERN cruise PS 81, ANT-XXIX/3, January-March 2013). PANGAEA. https://doi.pangaea.de/10.1594/PANGAEA.932856

Vanreusel A., Hauquier F., Beuselinck B., Van Gansbeke D. Viaene N. \& Veit-Köhler G. 2021b. Biotic water-column characteristics for stations from the North-Western Weddell Sea, Bransfield Strait, and Drake Passage (POLARSTERN cruise PS 81, ANT-XXIX/3, January-March 2013). PANGAEA. https://doi.pangaea.de/10.1594/PANGAEA.932771

Veit-Köhler G., Durst S., Schuckenbrock J., Hauquier F., Durán Suja L., Dorschel B., Vanreusel A. \& Martínez Arbizu P. 2018. Oceanographic and topographic conditions structure benthic meiofauna communities in the Weddell Sea, Bransfield Strait and Drake Passage (Antarctic). Progress in Oceanography 162: 240-256. https://doi.org/10.1016/j.pocean.2018.03.005

WoRMS Editorial Board 2021. World Register of Marine Species. https://doi.org/10.14284/170

Manuscript received: 16 August 2021

Manuscript accepted: 29 November 2021

Published on: 1 February 2022

Topic editor: Tony Robillard

Desk editor: Eva-Maria Levermann

Printed versions of all papers are also deposited in the libraries of the institutes that are members of the EJT consortium: Muséum national d'histoire naturelle, Paris, France; Meise Botanic Garden, Belgium; Royal Museum for Central Africa, Tervuren, Belgium; Royal Belgian Institute of Natural Sciences, Brussels, Belgium; Natural History Museum of Denmark, Copenhagen, Denmark; Naturalis Biodiversity Center, Leiden, the Netherlands; Museo Nacional de Ciencias Naturales-CSIC, Madrid, Spain; Real Jardín Botánico de Madrid CSIC, Spain; Zoological Research Museum Alexander Koenig, Bonn, Germany; National Museum, Prague, Czech Republic. 